\title{
Die Christelike filosofie van H. Dooyeweerd (1894-1977) soos gerekonstrueer volgens Vollenhoven se probleem- historiese metode
}

\author{
Author: \\ B.J. van der Walt ${ }^{1}$ \\ Affiliation: \\ ${ }^{1}$ School for Philosophy, \\ North-West University \\ South Africa \\ Correspondence to: \\ Bennie van der Walt \\ Email: \\ benniejvanderwalt@gmail. \\ com \\ Postal Address: \\ Bezuidenhout Street 7, \\ Oewersig, Potchefstroom \\ 2531, South Africa

\section{Dates:} \\ Received: 24 Nov. 2011 \\ Accepted: 16 May 2012 \\ Published: 17 July 2013 \\ How to cite this article: \\ Van der Walt, B.J., 2013, 'Die \\ Christelike filosofie van $\mathrm{H}$. \\ Dooyeweerd (1894-1977) \\ soos gerekonstrueer volgens \\ Vollenhoven se probleem- \\ historiese metode', In die \\ Skriflig/In Luce Verbi 47(1), \\ Art. \#94, 16 pages. \\ http://dx.doi.org/10.4102/ \\ ids.v47i1.94

\section{Copyright:} \\ (C) 2013. The Authors. \\ Licensee: AOSIS \\ OpenJournals. This work \\ is licensed under the \\ Creative Commons \\ Attribution License.
}

Read online:

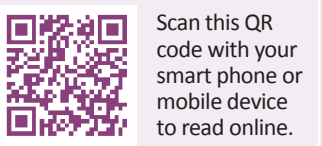

Hierdie inleidende, oorsigtelike artikel is die derde in 'n reeks van drie in hierdie tydskrif. Die kort trilogie beoog om die grondleggers van 'n Christelike filosofie, naamlik D.H.Th. Vollenhoven (1892-1978), H.G. Stoker (1899-1993) en H. Dooyeweerd (1894-1977) bekend te stel. In hierdie bydrae word gepoog om die hooftrekke van Dooyeweerd se komplekse filosofiese ontwikkelingsgang te rekonstrueer met behulp van sy Nederlandse kollega, Vollenhoven, se probleem-historiese metode van wysgerige historiografie. Ter inleiding word belangrike agtergrondinligting oor hierdie internasionaal erkende Christelike denker gegee. Daar word ook daarop gewys dat Dooyeweerd en Vollenhoven aan die begin (1918-1922) dieselfde filosofiese standpunt (wat deur Vollenhoven ontwerp is) gehuldig het. Mettertyd het hulle filosofiese paaie egter verskillend ontwikkel en groot verskille het in hulle konsepsies ontstaan. In die tweede gedeelte word eerstens daarop gewys dat Vollenhoven asook verskeie van sy leerlinge lank tevore reeds monargianistiese tendense by Dooyeweerd vermoed het. Sedert 2010 suggereer navorsing dat Dooyeweerd se filosofie oor ' $n$ periode van ongeveer 50 jaar deur ten minste die volgende drie verskillende fases ontwikkel het: 1918-1922 (kritiese realisme), 1923-1928 (semimistiek) en 1929-1977 (monistiese monargianisme). Met hierdie indeling as hipotese word daarna verskillende moontlike invloede op Dooyeweerd van binne die eie geesgenootlike kring sowel as daarbuite nagegaan. Laastens word enkele van sy uitstaande bydraes uitgelig. Op grond van 'n terugblik van al drie die bydraes in hierdie reeks, word ten slotte enkele opmerkings ten opsigte van die pad vorentoe gemaak.

The Christian philosophy of H. Dooyeweerd (1894-1977) as reconstructed according to the problem-historical method of Vollenhoven. This introductory overview is the third in a series of three in this journal. The aim of this trilogy is to introduce the founders of a Christian philosophy, viz. D.H.Th. Vollenhoven (1892-1978), H.G. Stoker (1899-1993) and H. Dooyeweerd (1994-1977) to the readers. The present article tries to reconstruct the contours of the complex philosophical development of Dooyeweerd by employing the problem-historical method of philosophical historiography of his colleague, Vollenhoven. The introduction provides important background information about this internationally acclaimed scholar. It is indicated that at the emergence of a reformational philosophy (1918-1922) these two thinkers shared a viewpoint mainly developed by Vollenhoven. Afterwards, however, their philosophical journeys developed in different directions, distinct from each other. A second section of the article draws attention to the fact that since long ago Vollenhoven and some of his followers suspected monarchian tendencies in Dooyeweerd's thinking. Since 2010 new research suggests that his philosophy developed during a period of about 50 years through at least the following three phases: 1918-1922 (critical realism), 1923-1928 (semi-mysticism) and 1929-1977 (monistic monarchianism). This hypothesis about Dooyeweerd's philosophical development enables a next (third) step, viz. to trace the possible internal influences (from his like-minded predecessors) as well as external (secular) ones on the formation of his thought. A following (fourth) part provides a few highlights of his contribution to Christian scholarship. Finally, in retrospection on all three articles, this contribution is concluded with a few remarks about the road ahead.

\section{Inleidende opmerkings}

Ter agtergrond die volgende opmerkings, veral vir lesers vir wie Dooyeweerd 'n onbekende figuur is.

\section{Aansluiting by vorige bydraes}

Hierdie artikel is die laaste van 'n trilogie in hierdie tydskrif wat oor die drie grondleggers van 'n Christelike filosofie handel. (Die aanbeveling is dat die leser al drie artikels sal bestudeer, 
aangesien hulle mekaar onderling aanvul.) Die eerste deel van die trilogie handel oor D.H.Th. Vollenhoven (1892-1978) en die tweede oor H.G. Stoker (1899-1993).

\section{Doelstelling}

In die heel eerste artikel is betoog dat 'n tradisie nie lewend kan bly indien dit nie aan 'n jonger generasie oorvertel word nie. Dit is ook die oogmerk van hierdie slotbydrae. Deur middel van ' $n$ oorsigtelike en bevatlike weergawe word die filosofiese erfenis van Herman Dooyeweerd (1894-1977) aan 'n nuwe geslag bekendgestel. Die verwagting is dat die geïnteresseerde leser die bibliografiese verwysings sal opvolg om daardeur self ' $n$ meer volledige beeld van die kontoere van Dooyeweerd se denke te verkry as wat in 'n artikel met beperkte lengte gebied kan word. Die skrywer is oortuig dat kennis van die filosofie - veral die Christelike filosofie - ook vir teoloë en ander wetenskaplikes van groot belang is.

\section{'n Belangrike denker}

Van die driemanskap (Vollenhoven, Stoker en Dooyeweerd) is laasgenoemde se filosofie internasionaal die bekendste. Die lywige gedenkbundel wat op sy 70ste verjaarsdag aan Dooyeweerd opgedra is (vgl. De Gaay Fortman et al. 1965) met ongeveer 30 bydraes van skrywers uit verskillende agtergronde en wêrelddele, getuig van sy wêreldwye bekendheid. In sy bydrae bespreek Klapwijk (1980) Dooyeweerd se belangrike bydrae in die 100 jaar wat filosofie aan die Vrije Universiteit beoefen word. By die herdenking van sy geboortejaar verskyn daar nog twee belangrike bundels (vgl. De Bruyn 1994 en Geertsema et al. 1994).

Dooyeweerd word as een van die mees kreatiewe Christelike denkers beskou (vgl. Young 1966). Hier onder volg twee evaluerings ten opsigte van die statuur van hierdie denker: '... without exaggeration Dooyeweerd can be called the most original philosopher Holland has ever produced, even Spinoza not excepted' (Kalsbeek 1975:10).

Wolters (1985) skryf van hom die volgende:

If the basic premise is granted that religion is necessarily a central factor in all philosophizing, then Dooyeweerd is a pioneer of heroic proportions in twentieth century philosophy ... he may prove to be a worthy modern follower of such Christian giants as Augustine from the early fifth century ... (bl. 17)

Soms word Dooyeweerd se bydrae egter oorskat en dit word selfs voorgestel asof sy wysbegeerte die enigste Christelike wysbegeerte is. Vollenhoven word as sy leerling beskou of hoogstens as 'n medewerker aan sy 'Wysbegeerte van die wetsidee' (later herdoop na 'Philosophy of the cosmonomic idea'). Soos sal blyk, bestaan daar behalwe die breë ooreenkomste ook ingrypende verskille tussen hierdie twee wysgere se filosofieë.

\section{'n Komplekse filosofie}

Selfs kenners van Dooyeweerd se filosofie erken dat dit nie eenvoudig is nie. Henderson (1994) skryf byvoorbeeld:
Dooyeweerd may be said to have the ambivalent honor of being a grand system builder ... The comprehensiveness of his philosophy is part of its grandeur but also a stumbling block to many interested in familiarizing themselves with it. Its immensity as a system makes it difficult to penetrate, challenging to comprehend ... (bl. 13)

Ook Chaplin (2011:3) maak melding van die 'great complexity and, at times obscurity of Dooyeweerd's thought'. Vir diegene wat nie die tyd of behoefte het om hulle in Dooyeweerd se massiewe oeuvre in te grawe nie, bestaan daar gelukkig eenvoudiger inleidings (vgl. Spier 1966 \& 1972, Kalsbeek 1975 \& 1983 en op 'n effens ingewikkelder vlak, Hommes 1982).

\section{Dooyeweerd se eie geskrifte en biografie in Engels}

Dooyeweerd se hoofwerke is die driedelige 'De wijsbegeerte der wetsidee' (1935-1936) en die verwerkte Engelse vierdelige vertaling daarvan, 'A new critique of theoretical thought' (1953-1958). Die Dooyeweerd Centre for Christian Philosophy (by die Redeemer University College in Ancaster, Ontario, Kanada) het' $n$ groot aantal dele van Dooyeweerd se versamelde werke reeds in Engels gepubliseer. (Besoek www.redeemer.ca/ Dooyeweerd-Centre en books@redeemer.ca vir bestellings.) Die direkteur van genoemde sentrum is dr Harry van Dyke en die redakteur van Dooyeweerd se versamelwerke is prof. D.F.M. Strauss (van Suid-Afrika). Tans word die publikasie van Dooyeweerd se werke voortgesit deur die Reformational Publishing Project (www.reformationalpublishingproject. com) en uitgegee deur Paideia Press, Grand Rapids.

Wie in Dooyeweerd se lewensgeskiedenis belangstel, kan die biografie van Verburg (1989) raadpleeg ('n Engelse weergawe daarvan verskyn binnekort by Paideia Press, Grand Rapids, Michigan).

\section{Heelwat sekondêre bronne}

Die hoeveelheid lektuur oor Dooyeweerd se denke het buitengewoon gegroei. Henderson (1994:voetnote op bl. 13-14) bied 'n lysie van nie minder nie as 'n twaalftal proefskrifte oor verskillende fasette van Dooyeweerd se denke. Na hierdie tydperk het die produksie van wetenskaplike boeke oor sy filosofie ook nie stilgestaan nie. Slegs enkele meer resente voorbeelde is dié van Choi (2000), Strauss en Botting (2000), Chaplin (2011) en Ive (2012). Elkeen van hierdie boeke bied in hulle onderskeie bibliografieë nog veel meer bronne. Hiermee is nog nie eers die talle artikels in akademiese tydskrifte en versamelwerke genoem nie.

\section{Nogtans nie die verwagte invloed}

Ten spyte van wat tot sover oor Dooyeweerd en sy filosofie gesê is, merk Zylstra (1975:29) op: 'It has not exerted the influence one might have expected, not in its homeland nor elsewhere.' Hy noem verskllende redes vir die kleiner-asverwagte impak soos onder andere die sekulêre klimaat van die twintigste eeu; dat Dooyeweerd se hoofwerk (' $A$ new critique of theoretlical thought', 1953-1958) swak in Engels 
vertaal is en dus konteksloos in die Engelssprekende wêreld beland het; die feit dat Dooyeweerd se filosofie op baie punte kontroversieel was (bv. sy verwerping van die eeu oue dualisme tussen natuur en genade, sy visie op die teologie as wetenskap en die sosio-ekonomies-politieke implikasies van sy denke); en die situasie onder verskillende geledinge van die Protestantisme.

Van laasgenoemde noem Zylstra (1975) dat die Ortodokse Protestantisme nie 'n suiwer Christelik-filosofiese tradisie gehad het nie, terwyl die liberale Protestantisme meestal eklekties te werk gegaan het. Van die eerste groep sê Zylstra (1975) vervolgens:

Orthodox Protestantism, in its Lutheran, Reformed, Anglican, and numerous conformist persuasions, has not developed a Christian philosophy that could serve as a worthy alternative to Neo-Thomist and humanist philosophies. This meant that the academic leaders of orthodox Protestantism were theologians, not particularly interested in philosophical matters and generally not conscious of the philosophical assumptions that had surreptitiously crept into their theological systems. In view of this it is not all together surprising that this new philosophy was little understood and less appreciated in theological circles. (bl. 29-30)

Hierdie uitspraak dien as ' $n$ verdere motivering vir die skryf van hierdie en die twee vorige artikels in 'n teologiese tydskrif. 'n Evangeliese teoloog, Mitchell (2007) skryf byvoorbeeld:

$[I] \mathrm{t}$ is my experience that too many theologians know enough of philosophy to be dangerous, but not enough to be competent. As a result they try to combine Christian theology with incompatible philosophical systems ... Just as problematic as theologians who are not aware of the philosophical presuppositions are theologians who use philosophy badly ... there are those who attempt to resurrect dead philosophical ideas. (bl. 13)

\section{Probleemstelling en hipotese}

Hierbo is reeds genoem dat Dooyeweerd se filosofie ingewikkeld en moeilik analiseerbaar is om in ' $n$ geheelbeeld saamgevat te kan word.

\section{Dooyeweerdiaanse interpretasies alleen help nie}

Hierdie probleem word ook nie opgelos deur die stroom geskrifte oor Dooyeweerd nie, hoe waardevol dit ook al is. Die rede hiervoor is dat die geskrifte meestal op Dooyeweerdiaanse interpretasies van sy denke neerkom. By navolgers wat Dooyeweerd se denke simpatiek gesind is, vind 'n mens wel kritiek daarop, maar dit is meestal óf 'n verdere verwerking, óf 'n uitbouing van sekere fasette daarvan (vgl. Kock 1973 en meer resent, sekere hoofstukke in Strauss \& Bonting 2000), óf misverstande oor sy wysbegeerte wat uit die weg geruim word (bv. Strauss 2004 \& 2006b).

Die kritiek wat hy van geesgenote (soos Vollenhoven en Stoker en hulle navolgers - vgl. vorige artikels) ontvang het, is meestal ook op onderdele van sy filosofie toegespits en dit help 'n mens dus nie om 'n geheelbeeld van Dooyeweerd te vorm nie.
Wolters (1985:1 e.v.) toon duidelik die verskillende invloede van die destydse filosofiese milieu op Dooyeweerd se filosofie aan. Hy konsentreer egter hoofsaaklik op individuele denkers en stromings se moontlike invloede. Hy suggereer wel moontlike fases in Dooyeweerd se denke, maar dui dit tog nie duidelik aan nie.

Kraay (1979 \& 1980) se bydraes handel ook oor verskillende sleutelkonsepte in die ontwikkeling van Dooyeweerd se denke. Eers val die klem op die lewensbeskoulik-religieuse, daarna op 'n Archimedespunt, wetsidee, en vanaf 1939 op grondmotiewe en transendentale kritiek. Dit word daarvolgens duidelik dat Dooyeweerd se filosofie wel ontwikkel het, maar die ontwikkelingsgang word alleen na aanleiding van belangrike nuwe konsepte by Dooyeweerd geteken en ook nie duidelik in fases of periodes ingedeel nie.

\section{Hipotese}

Die hipotese van die skrywer van die onderhawige artikel is die volgende: (1) 'n beter perspektief op die geheel van Dooyeweerd se filosofie is bereikbaar indien dit moontlik sou wees om in sy ontwikkeling duidelik verskillende denkfases te onderskei en te tipeer; (2) sodanige wendings in sy denke kon die gevolg wees van die beïnvloeding deur ' $n$ bepaalde denker of denkstroming; (3) 'n rekonstruksie kan eerder van buite as van binne die Dooyeweerdiaanse tradisie gedoen word, aangesien dit die nodige afstand bied; (4) hierdie blik op Dooyeweerd mag egter nie religieus onverskillig teenoor sy ideaal van 'n Christelike filosofie staan nie.

So 'n benadering is eerstens moontlik omdat die grondliggende Christelike lewensvisie van die driemanskap wel ooreengekom het, maar die filosofiese uitwerking daarvan verskil het. In die tweede plek is so ' $n$ aanpak nie ongewoon of noodwendig onregverdigbaar nie. Malan (1968) en Kock (1973) het byvoorbeeld reeds Stoker se denke vanuit 'n Dooyeweerdiaanse hoek benader. Die feit dat verskillende reformatoriese denkers verskillende standpunte huldig, hoef ook nie negatief beoordeel te word nie. Dit bewys dat hulle nie napraters was wat almal dieselfde filosofiese deuntjie gesing het nie.

Voordat gepoog word om Dooyeweerd se ontwikkelingsgang vanuit 'n Vollenhoveniaanse perspektief te rekonstrueer, moet die aandag egter eers op hulle onderlinge verskille gevestig word.

\section{Verskille tussen die filosofieë van Dooyeweerd en Vollenhoven}

Tot onlangs nog was daar groot onduidelikheid oor die ooreenkomste en verskille in die filosofieë van Dooyeweerd en Vollenhoven. Dooyeweerd het hom nie oor die verskille tussen hulle uitgespreek nie. Hy was eerder geneig om Vollenhoven se filosofie met sy eie te identifiseer deur laasgenoemde sy 'medewerker' te noem (vgl. Dooyeweerd $1935,1: 33)$ en later selfs net 'n blote 'aanhanger' daarvan (vgl. Dooyeweerd 1953, 1:31, voetnoot). Hierdeur is navolgers van 
Dooyeweerd ook mislei deur te dink dat daar eintlik geen of weinig verskil tussen Dooyeweerd en Vollenhoven se Christelike filosofie bestaan het nie.

\section{Onderlinge verskille erken}

Reeds in die vorige twee artikels (Van der Walt 2013a en 2013b) is die aandag op die verskille in hulle filosofieë gevestig. Soos aangetoon (Van der Walt 2013a), het Vollenhoven en Dooyeweerd hulle verskille egter nie aan die groot klok gehang nie - 'n gesamentlike front was van strategiese belang vir 'n reformatoriese beweging. Op grond van 'n besluit van die Vereniging voor Calvinistische Wijsbegeerte (1947) stel Vollenhoven egter ' $n$ 'divergensierapport' op, wat eers veel later weer in die Vollenhoven-argief ontdek is en nog later (Vollenhoven 1992:107-117) gepubliseer is. Daaruit blyk dat Vollenhoven se denke onder andere die volgende verskilpunte met Dooyeweerd gehad het: die verhouding van die wet en die wetsonderworpene (subjek); tyd; die menslike hart (wat Dooyeweerd as bo-tydelik beskou het en Vollenhoven nie); die aard van religie; verskillende kwessies van kenteoretiese aard. Wolters (1985:16) wys verder daarop dat Vollenhoven nooit met die volgende idees van Dooyeweerd kon saamstem nie: sy transendentale kritiek, die skepping as $\sin$ (meaning), kosmiese tyd; en sy analise van die Westerse denke volgens vier religieuse grondmotiewe.

Al hierdie verskille spruit uit die dieper, grondliggender ontologiese vertrekpunte tussen Vollenhoven en Dooyeweerd. Eenvoudigheidshalwe kan dit soos volg gestel word: Vollenhoven gaan in sy finale werklikheidsvisie van die radikale (ontiese) verskil tussen God, sy wet en sy skepping uit asook hulle (religieuse) verbondenheid. Dooyeweerd onderskei uiteindelik tussen God (as ewig), die menslike hart (as bo-tydelik) en die res van die kosmos (as tydelik), wat sowel 'n wets- as subjeksy insluit.

\section{Ook deur hulle navolgers raakgesien}

Sommige van hierdie verskille is ook deur sowel Vollenhoven as Dooyeweerd se navolgers opgemerk. Zylstra (1975:22-23) skryf byvoorbeeld dat daar nie 'n belangrike filosofiese probleem is wat die twee nie op 'n eie wyse ontwikkel het nie. Hy noem weereens hulle teorieë oor die menslike hart, die modaliteitsleer, hulle visie op tyd, die epistemologie en die plek van die Bybel in teoretiese refleksie - ook in die filosofie. Laasgenoemde verskil blyk byvoorbeeld uit die oriënterende wyse waarop Vollenhoven voortdurend van die Skrif gebruik maak (vgl. Vollenhoven 2011).

\section{'n Eensydige beeld}

Ten spyte van Strauss se toewyding om die denke van Dooyeweerd wêreldwyd bekend te stel (Strauss 2009 - 'n boek van 700 bladsye), verskil ek van my Bloemfonteinse kollega oor die groot ooreenkomste tussen Dooyeweerd en Vollenhoven (vgl. Strauss 2006a). Hy bespreek wel ook vier verskille (Strauss 2006a:26-34), maar lê tog oorwegend klem op hulle ooreenkomste. Die ooreenkomste sou volgens hom veral op drie punte na vore kom, naamlik Dooyeweerd en Vollenhoven se onderskeid tussen God en die skepping en hulle klem op God se wette vir die skepping; hulle grondidees; en hulle modaliteitsleer. Ek twyfel egter sterk oor hierdie ooreenkomste (vgl. wat hierbo reeds daaroor gesê is).

Ek skryf hierdie, myns insiens, eensydige konklusie van Strauss hoofsaaklik daaraan toe dat alhoewel hy van Vollenhoven se sistematiese denke (in sy Isagôgè) kennis geneem het (waaroor Vollenhoven na 1940 nie verder gepubliseer het nie), hy waarskynlik nie Vollenhoven se later ontwikkelde probleem-historiese metode (vgl. die eerste artikel in hierdie trilogie) ter sprake bring nie. Vollenhoven het sy eie metode voortdurend tot 1975 aangepas en hierdie veranderings het ook groot implikasies vir sy eie sistematiese filosofie ingehou.

\section{Nuwere navorsing}

Zylstra (1975:23) skryf vroeër dat die verhouding tussen Dooyeweerd en Vollenhoven se denke nie duidelik is nie. 'The history of their relationship, their mutual influences, their differences, and their respective contributions still needs to be researched and explicated.' Ook Wolters (1985) het reeds lank tevore daarop gewys dat toe Dooyeweerd in die filosofie begin belangstel het, Vollenhoven alreeds in die filosofie gepromoveer en artikels op hierdie vakgebied geskryf het. Wolters (1985) poneer:

It would be quite misstaken to picture Vollenhoven as a kind of second fiddle to Dooyeweerd's genius. On the basis of Vollenhoven's early publications, a good case can be made for the thesis that he in some significant ways shaped the developing systematic philosophy of Dooyeweerd. (bl. 16)

Hierdie hipotese van Wolters is intussen deur die proefskrif van Tol (2010a:263 e.v.) bevestig asook in die samevatting daarvan (Tol 2011a \& 2011b).

\section{Dooyeweerd se ontwikkeling vanuit 'n Vollenhoveniaanse probleem-historiese perspektief}

'n Benadering van Dooyeweerd se denke vanuit Vollenhoven se probleem-historiese metode vind ' $n$ mens by Vollenhoven self asook by Vollenhoven se navolgers. Hierdie metode maak van 'n eie, unieke terminologie gebruik, waarvan die betekenis nie vir alle lesers van hierdie artikel duidelik mag wees nie. Binne die beperkte lengte van die artikel sal slegs die belangrikste terme verduidelik kan word. Daarom word Bril (1986), as 'n maklik verstaanbare weergawe van Vollenhoven se metode, aanbeveel.

\section{Vollenhoven oor die moontlike invloede op Dooyeweerd}

Soos reeds genoem, het Vollenhoven hom selde en dan slegs terughoudend oor die filosofiese standpunte van sy kollega, Dooyeweerd, uitgelaat (vgl. Brill aangehaal in Vollenhoven 2000:92, voetnoot 11). Aanvanklik het Vollenhoven in Dooyeweerd se filosofie ' $n$ tipe Platoniserende, dualistiese monargianisme gesien, maar sedert 1959 as 'n semimistieke denker. Vanaf 1973 interpreteer hy Dooyeweerd as 'n monistiese monargiaan - 'n nuwe tipe wat Vollenhoven 
onderskei het. Vollenhoven wys egter net op vermeende invloede op Dooyeweerd en het, sover my bekend, nooit iets eksplisiets ten opsigte van ' $n$ ontwikkelingsgang by Dooyeweerd gerep nie.

\section{Navolgers van Vollenhoven}

Verskeie van Vollenhoven se studente het hulle ook oor Dooyeweerd se denke uitgelaat.

\section{Peter Steen (1935-1984)}

Steen (1983) het reeds in 1970 probeer om die geheelstruktuur van die Dooyeweerdiaanse filosofie hoofsaaklik volgens Vollenhoven se probleem-historiese metode (soos tot op daardie tyd) te rekonstrueer (m.a.w. sonder die belangrike insigte wat Vollenhoven na 1970 ontwikkel het). Hy kon egter nie sê dat hy bevredigend daarin geslaag het nie. Hy vind byvoorbeeld aanvanklik 'n prioriteitsleer by Dooyeweerd, maar sê later (Steen 1983:255) dat Dooyeweerd ook net sowel 'n monargiaan kon gewees het. Hy vermeld wel 'n moontlike ontwikkeling in Dooyeweerd se denke, maar skep terselfdertyd die indruk dat Dooyeweerd dwarsdeur sy loopbaan dieselfde konsepsie sou gehuldig het. (Heel moontlik is dit die rede waarom Steen tussen sulke verskillende tiperings van Dooyeweerd geweifel het.)

Steen se rekonstruksie van Dooyeweerd se filosofie het om die een of ander rede nie die aandag ontvang wat dit, myns insiens, verdien het nie. Omdat Steen nie Vollenhoven se latere probleem-historiese navorsing tot sy beskikking gehad het by die skryf van sy proefskrif (1970) nie, is dit verstaanbaar dat hy Dooyeweerd nie duideliker kon tipeer nie. Hy het nogtans Dooyeweerd se geskrifte grondig bestudeer en dit wat hy destyds gevind het, kan vandag met die beskikbare nuwe kennis baie nuttig gebruik en georden word. Slegs enkele punte van sy belangrike bydrae word hier uitgelig.

Steen (1983:201, 210, 254-255) bied belangrike gegewens oor Dooyeweerd se vroeë kritiese realisme (deur Steen as neo-realisme aangedui).

Hy toon aan dat Dooyeweerd se idee van 'n bo-tydelike hart 'n sleutelrol in sy hele filosofie speel. Verder toon hy met sitate uit Dooyeweerd self aan (vgl. Steen 1983:219, 253) dat Dooyeweerd sy idee van die hart as aevum (geskape ewigheid of bo-tydelike) aan die skolastieke filosofie, spesifiek aan Thomas van Aquino, ontleen. Hy wys ook op die implikasies daarvan, naamlik die moontlike depresiasie van skepping en tyd.

Verder beskryf Steen (1983:51-71, 191-193) ook duidelik die twee rigtings in Dooyeweerd se denke, naamlik van bo (die ewige) af 'n diversifikasie na die tydelike verskeidenheid en van onder af 'n konsentrasie op die ewige Eenheid. (Dus nie eenheid in verskeidenheid nie, maar eenheid bo verskeidenheid.) 'n Gerigtheid op die aardse, tydelike word dus te maklik as afgodery beskou, terwyl 'n gerigtheid op die ewige ware geloof sou inhou.
Dooyeweerd se idee van die sinkarakter van die skepping word ook duideliker uit Steen se werk. Steen (1983:83, 222, $224,255)$ wys daarop dat Dooyeweerd waarskynlik struktuur en rigting verwar. Hy verstaan die religieuse rigting (bv. die uitreik van die mens in geloof tot God) as 'n ontiese uitwys bo die skepping uit. Heel waarskynlik het Dooyeweerd hierdie gedagte ontleen aan die Thomistiese idee van 'n natuurlike strewe (desiderium naturale) vanuit die terrein van die natuur na die bonatuurlike.

'n Laaste, maar belangrike ontdekking van Steen is dat Dooyeweerd - ten spyte van al sy kritiek op die RoomsKatolieke leer van natuur-bo-natuur - sy eie denke tog nie daarvan kon bevry nie, maar dit slegs aangepas het.

Dooyeweerd (1928) stel sy eie standpunt soos volg:

Niet de natuur als voortrap der genade, gelijk in het RoomsKatholisisme, geen heidens fundament onder christelijk kap. Geen in wezen onverzoende breuk tusschen natuur en genade, gelijk in het Lutheranisme, maar natuur en genade in onverbrekelijke, harmonischen samehang'! (bl. 27) (Vir Steen se kritiek hierop, vgl. Steen 1983:114-124)

Dit wil voorkom asof Dooyeweerd se bo-tydelike hart (aevum) en dié se strewe na die ewige Oorsprong die skakel vorm, of die harmonie tussen (tydelike) natuur en (ewige) genade waarborg.

\section{Harry Fernhout}

Volgens Fernhout dink Dooyeweerd ook (heel waarskynlik dualisties) binne 'n monargianistiese raamwerk. Fernhout (1975:74-76) sien hierdie trek daarin dat die hoogste dimensie van menswees, die hart, wat bo-tydelik, bo-liggaamlik en bo-modaal sou wees, die sentrale, regerende en verenigende faktor van menswees is asook die beeld van God sou weerspieël. Vanuit hierdie religieuse konsentrasiepunt word die hele skepping gerig asook die verskeidenheid tot 'n eenheid saamgetrek. Dit dien verder as 'n skakel waardeur God (as Monarg) die wêreld bestuur. Fernhout gaan van die veronderstelling uit dat Dooyeweerd hierdie konsepsie dwarsdeur sy lewe gehuldig het.

\section{Jan Taljaard (1915-1994)}

Taljaard, wat onder Vollenhoven gepromoveer het, bespreek verskillende fasette van Dooyeweerd se denke ' $n$ jaar later (vgl. Taljaard 1976:300 - indeks waarin die verskillende bladsye aangegee word).

Taljaard (1976:84 e.v.) toon die parallelle aan tussen Aristoteles (in sy latere monargianistiese fase), Thomas van Aquino (in die eerste monargianistiese periode van sy denke) en Dooyeweerd se ontologie. Heel bo-aan die synshiërargie is die godheid (monarg); dan volg 'n goddelike, bo-persoonlike, universele denkgees, wat individuele uitlopers het; daarna (op 'n laere vlak) volg die individuele menslike geeste en (nog laer) die res van die skepping. Die hoëre synsdele (monarg en denkgees) druk hulself in die laere (mens) uit en die laere (die mens en die res van die kosmos) wys terug na die hoëre. 
Dooyeweerd se monargianistiese antropologie is volgens Taljaard aangevul met Thomas se leer van die analogie van die syn en die hart as iets bo-tydeliks teenoor 'n tydelike liggaam. Ook hier kom die ekspressiewe rigting na onder en die terugwysende na bo (vgl. Steen \& Fernhout hierbo) weer duidelik na vore (vgl. Taljaard 1976:107-108).

Volgens Taljaard aanvaar Dooyeweerd dus twee oorspronge ('n dubbele monisme), naamlik God as ewige oorsprong van alles wat bestaan en die mens as 'n laere oorsprong van die tydelike wêreld. Elkeen van hierdie oorspronge divergeer na onder in verskeidenheid en trek na bo saam in eenheid, eers in die menslike hart en dan in Christus.

Dooyeweerd se religieuse grondmotiewe beskou Taljaard (1976:157) as uitlopers van die werk van die bo-individuele denkgees (direk onder die monarg). Taljaard (1976:273 e.v.) verklaar Dooyeweerd se kenteorie ook in die lig van sy monargianistiese werklikheids- en mensvisie.

\section{'n Ontwikkelingsgang by Dooyeweerd}

Hoewel hulle onderling saamstem dat Dooyeweerd se filosofie 'n sterk monargianistiese kleur het, meld nóg Vollenhoven nóg sy navolgers of dit dwarsdeur sy lewe die geval was. Nêrens opper hulle dus die moontlikheid van 'n duidelike ontwikkeling en dus verandering in sy denke nie.

\section{Nuwere navorsing}

Hedendaagse navolgers van Dooyeweerd se denke is egter meer bewus van 'n moontlike ontwikkeling in sy denke. Chaplin (2011:25) skryf byvoorbeeld dat, hoewel die essensiële struktuur van Dooyeweerd se filosofie teen ongeveer die middel van die dertigerjare van die twintigste eeu geformuleer is, dit nie verbasend sou wees indien daar gedurende die vyf dekades waarin hy gepubliseer het belangrike verskuiwings plaasgevind het nie. Ongelukkig is Chaplin se werk op Dooyeweerd se samelewingsfilosofie gefokus en die diepere, ontologiese ontwikkelingsfases kom nie duidelik in die res van Chaplin se andersins uitstekende werk na vore nie.

Drie fases by Dooyeweerd te onderskei: Hierdie leemte is onlangs deur die navorsing van Tol (2010a) gevul. Hy onderskei 'n duidelike ontwikkelingsgang in ten minste die volgende drie fases: Dooyeweerd 1 strek vanaf 1918-1922, Dooyeweerd 2 vanaf 1923-1928 en Dooyeweerd 3 vanaf 1928-1977 (sy finale standpunt). In die eerste fase sluit Dooyeweerd by die (vroeëre) standpunt van Vollenhoven aan, naamlik kritiese realisme, wat nog slegs 'n modifikasie van die gereformeerde skolastieke denke was. In fase 2 huldig hy 'n semimistieke konsepsie in navolging van Augustinus, Calvyn en veral Kuyper. Sy finale, derde konsepsie is 'n monistiese monargianisme met ' $n$ besondere sterk vorm van mistiek in navolgling van die Griekse denker Speusippos, die neo-Platoniese Plotinos, die renaissance-denker, Cusanus en veral die neo-idealistiese (rasionalistiese) filosoof, Husserl.
Die heel jongste hipotese: Heel onlangs stel Tol die volgende hipotese (vgl. Tol 2012). Hierin voeg hy tussen Dooyeweerd 2 en 3 nog 'n tussenfase by. Hy onderskei met ander woorde die volgende vier fases:

- D1 (tot 1922) dink krities-realisties: sy wetsidee (ideë) beheers ook die individuele dinge.

- D2 (vanaf 1922 en 1923) huldig 'n semimistieke filosofie met nog steeds ' $n$ krities-realistiese invloed as gevolg van sy wetsidee as wêreldplan.

- D3 (vanaf 1928) dink dualisties-monargiaans met sy wetsidee nou as 'n transendentale idee van kritisisme. As gevolg van die voortgaande semimisstieke invloed lê hy nadruk op die sinkarakter van die werklikheid, wat die materiële byna oorbodig maak. Sy wetsidee word nie meer as (goddelike) wêreldplan beskou nie, maar transendentaalkrities gelei deur die menslike ek wat transendent is ('n van bo na onder-benadering).

- In D4 (vanaf c. 1940) tree sy vier religieuse grondmotiewe na vore. Die ek is nou nie meer transendent nie, maar transendentaal (van onder na bo-benadering). Dooyeweerd se dualistiese terminologie maak plek vir 'n monistiese terminologie. (Die nog krasser mistieke lyn van Plotinos, Cusanus en Husserl is hier relevant.)

Omdat dit vir oningewyde lesers te ingewikkeld raak, word nie verder op hierdie nuutste hipotese van Tol ingegaan nie, maar voorlopig word by 'n indeling in drie fases gehou.

\section{Versigtigheid gewens}

Dit sou nie buitengewoon wees indien Dooyeweerd 'n ontwikkeling deurgemaak het nie - dit kom by talle denkers dwarsdeur die geskiedenis voor. Indien daar nie van 'n krisis en 'n radikale breuk sprake is nie, is daar gewoonlik onduidelikheid by die oorgang van die een na die ander tipe filosofie - daar bly dus spanning oor in so 'n persoon se denke. Om in 'n denker se ontwikkelingsgang sekere fases te onderskei, beteken dus nie noodwendig om dit in waterdigte of abrupte chronologiese periodes in te deel nie. Die oorgange kan geleidelik wees en dus nie skerp afgebaken wees nie. Dit is nie altyd maklik om aan te toon waar een invloed swakker word of ophou en 'n ander sterker word nie. Nogtans kan dit van groot hulp wees om 'n denker beter te verstaan en 'n geheeloorsig van sy denke te verkry.

Wolters (1985) behandel die invloede op Dooyeweerd baie versigtig. Soms sê hy dat dit moontlik eenvoudige woordelikse en nie-inhoudelike ooreenkomste mag wees; ander kere weer dat Dooyeweerd die denkgoed wat hy van ander denkers oorgeneem het op 'n eie manier verwerk het; nog 'n ander keer dat die ooreenkomste tussen Dooyeweerd en ' $n$ ander denker verdere ondersoek vereis; en ten slotte dat dit eenvoudig onduidelik is om te bepaal wat 'n betrokke invloed op hom was.

\section{Die geheelprentjie}

Indien Tol se analise van die denkontwikkeling van Dooyeweerd korrek is (navolgers van Dooyeweerd mag dit moontlik bevraagteken), bied dit 'n goeie oorsig oor sy hele 
filosofie. Dit verklaar waarom verskillende konsepte op bepaalde tye in sy denke na vore kom of meer prominent word. Verder verhelder dit ook sy voorliefde vir sekere voorafgaande of kontemporêre denkers gedurende 'n sekere tyd van sy loopbaan. Wanneer sy oeuvre bestudeer word, kan die datums van die drie (of vier) fases dus ook in gedagte gehou en selfs verander word.

Vervolgens sal iets meer oor elkeen van hierdie drie fases gesê word, asook oor die figure of filosofiese stromings wat gedurende 'n bepaalde tyd moontlik Dooyeweerd se filosofie kon beïnvloed het.

\section{Moontlike invloede op Dooyeweerd se filosofie gedurende die drie fases van sy denke}

Soos in die geval van Vollenhoven en Stoker (vgl. die twee vorige artikels in hierdie tydskrif - Van der Walt 2013a en $2013 b$ ) is Dooyeweerd sowel van binne (sy eie geesgenootlike tradisie) as van buite (die sekulêre filosofieë van destyds) beïnvloed.

\section{Die beginfase van Dooyeweerd en Vollenhoven: 1918-1922}

Dooyeweerd (bv. 1973:8) noem herhaaldelik dat hy en Vollenhoven veral hulle posisie teenoor twee stromings moes bepaal - en onbewustelik in hulle reaksie ook daardeur beïnvloed is - wat in hulle beginjare invloedryk was en elkeen 'n eie kenteorie voorgestaan het.

\section{Twee destydse rigtings}

Aan die een kant is die eie geesgenootlike rigting, veral Kuyper se lewensbeskoulike herformulering van die gereformeerde skolastieke teologie ter sprake. Aan die ander kant was daar die humanisties-geïnspireerde latere rasionalisme van die idealisme van veral die neo-Kantiane waarmee hulle gekonfronteer is. Elkeen van hierdie twee wou op 'n eie wyse aantoon hoe die subjek (kenner) en objek (kenbare dinge) bymekaar kom. Die Skolastiek het op grond van die logosleer (wette as werklike 'dinge' in die skepping en in die mens se intellek; d.w.s. 'n vorm van realisme) aanvaar dat daar ooreenstemming tussen denke en syn kan wees. Die neo-Kantiane het hierdie ooreenstemming verwerp en geleer dat kennis bloot ' $n$ redelike konstruksie van die mens is, sodat die eksterne werklikheid as 't ware sy waarde verloor het. Dit is dus te verstane dat Vollenhoven en Dooyeweerd aanvanklik hulself meer tuis gevoel het in die gereformeerdortodokse denke waarin hulle opgegroei het.

Vir oningewydes in die geskiedenis van die Westerse filosofie is die volgende verduideliking gepas. Vanaf ongeveer 1600 tot 1900 was die dominante stroming die Rasionalisme. Daarvolgens is die menslike verstand (ratio) as norm vir die teorie en die praktyk verabsoluteer. As gevolg van onderlinge aksentverskille kan die rasionalistiese denke in twee hoofperiodes ingedeel word, naamlik die vroeëre en/ of ouer Rasionalisme (c. 1600-1830) en die latere of jongere
Rasionalisme (c. 1830-1900). Binne die ouere Rasionalisme was daar egter drie afsonderlike bewegings: scientialisme, praktikalisme en (ou) idealisme (bv. Kant). In die jongere Rasionalisme kom parallelle stromings voor, naamlik positivisme, verruimde positivisme of neo-Aufklärung en die neo-idealisme. Die neo-Kantiaanse filosofie, populêr ten tye van Dooyeweerd, val onder laasgenoemde stroming (vgl. Vollenhoven, 2005b:75-83).

\section{Vollenhoven ongeveer 1918-1922}

As inleiding tot sy promosie (vgl. Tol 2010b) bied hy 'n kort samevatting (vgl. Tol 2010a veral bl. 294), wat hier weergegee word. Hieruit blyk sowel die moontlike aanvanklike oorname van Vollenhoven se semiskolastieke standpunt deur Dooyeweerd asook hoe hulle later altwee hulle aanvanklike gemeenskaplike visie prysgegee en elkeen sy eie weg gegaan het.

Gedurende die beginfase sedert sy proefskrif (1918) is Vollenhoven se konsepsie nog nie baie duidelik nie. Wat wel duidelik is, is dat hy toe nog baie na aan die gereformeerde skolastieke tradisie van sy leermeester, Woltjer en sy baie voorgangers, gestaan het. Dit was 'n kritiese realistiese tradisie wat in die vorm van 'n logosspekulasie uitgewerk was. Vollenhoven dui sy eie posisie op hierdie stadium aan as transendentale of kritiese realisme.

Hierdie siening kom kortliks op die volgende neer. Die wêreld bestaan omdat dit gegrond is in ideë. (Die wêreld en sy ideë of wette is weer gegrondves in die ewige Raad van God, in die goddelike Gees.) Om die wêreld te ken, impliseer dus veel meer as om slegs die verskynsels waar te neem. Kennis vereis kritiese ordening waarvoor logiese norme geld. Die kennis wat die mens op hierdie wyse van die wêreld verkry, is op 'n aantal basiese intuïsies (invloed van Bergson) gebaseer, wat sou waarborg dat dit wetenskaplike kennis is.

Vollenhoven onderskei 'n drieslag van wêreld, mens en wetenskaplike kennis. Omdat die wêreld met sy redelike ideë in die ewige Raad van God gegrondves is, word die menslike denke begelei deur norme wat van die goddelike Gees afkomstig is. Die goddelike Logos (Woordopenbaring) is die waarborg vir die harmonie tussen die subjek (kenner) en die objek (kenbare). Harmonie bestaan tussen die objektiewe rasionaliteit van die wêreldorde (idees) en die subjektiewe rasionaliteit van die menslike denke.

Die eeue oue wetsidee wat grondliggend tot hierdie beskouing is, is waarskynlik ' $n$ verwerking van die tipies skolastieke beskouing wat byvoorbeeld baie duidelik by Thomas van Aquino (1224-1274) aangetref word. Die oorspronklik Platoniese idees, as dinge (Latyn: res) beskou (vandaar realisme), is in die Christelike tradisie verander. Die idees (wette) bestaan naamlik ante rem, in die intellek en/of gees van God; God skep hulle in rebus, in die geskape dinge in; hierdie goddelike idees of redelike wetskieme in die dinge kan deur die mens geabstraheer word, sodat hulle ook post rem, deur die menslike verstand begryp kan word. Die garansie dat korrekte, wetenskaplike kennis van die wette (logoi) 
bekom is (met ander woorde die ooreenstemming tussen die wetskieme in rebus, in die dinge, en die wetskennis post rem, in die menslike rede of logos), word deur die goddelike Logos, God se openbaring in die Skrif en uiteindelik in Christus (die Logos) verskaf. (Vgl. egter Vollenhoven 2005a:348-349 wat die aandag daarop vestig dat die term realisme in baie verskillende betekenisse gebruik word en dat hier dalk nie so 'n direkte lyn loop nie.)

\section{Dooyeweerd gedurende die begin van die twintigerjare van die vorige eeu}

Gedurende hierdie tyd huldig Dooyeweerd blykbaar dieselfde standpunt as Vollenhoven en hy noem sy standpunt (net soos Vollenhoven) 'kritiese realisme'. Toe Dooyeweerd na sy regstudie sy eie filosofie begin ontwikkel het, en hulle twee saam in Den Haag gewoon en noue kontak gehad het, het hy waarskynlik heelwat by sy swaer, Vollenhoven, geleer.

\section{Vollenhoven tot ongeveer 1922}

Janse van Biggekerke (1890-1960), wat destyds korrespondensie met Vollenhoven onderhou het, het egter kritiese vrae oor 'n belangrike onderdeel van die destydse skolastieke gereformeerde denke (ook gereformeerde ortodoksie genoem) begin stel, naamlik oor die idee van die onsterflike, redelike siel. Hy het uit die Skrif aangetoon dat dit ' $n$ onbybelse, heidense gedagte is. (Vir meer oor Janse, vgl. Van der Walt 2008:189-229).

Hierdie gedagtes van Janse het Vollenhoven sedert die middel van 1922 gestimuleer om sy antropologie (vgl. stelling 19 en 25 tydens sy promosie in 1918) opnuut te heroorweeg. Die posisie van die kennende mens verander. Wetenskaplike denke word nou nie meer afhanklik gemaak van 'n veronderstelde onsterflike, redelike siel nie (die post rem-idee), maar is afhanklik van die orde van die wêreld self. Hy hou egter nog steeds vas aan ' $n$ afgeskaalde soort realisme (die idee van die wet 'in rebus', in die geskape werklikheid).

In die somer van 1922 kom daar 'n wending toe Vollenhoven met 'n volledige skolastieke realisme (wat ook dingwette in God en in die mens sou insluit) breek. Hy begin ook besef dat daar nie 'n polariteit tussen subjek (kenner) en objek (kenbare) bestaan nie, maar dat kennis en om te ken self deel van die geskape werklikheid is. Die kenbare werklikheid is vir hom dus nie langer vreemd aan logiese denke nie.

Onder die invloed van Janse se antropologie (wat die idee van die siel as 'n onsterflike substansie verwerp het) verloor die intellek self (tradisioneel as die hoogste funksie van die siel beskou) ook sy outonomie en betekenis. Die redelike of logiese is nou slegs 'n funksie van die totale werklikheid. (Vollenhoven se modaliteitsleer is waarskynlik beïnvloed deur die regionale kategorieë van die Freiburgse neo-Kantiaan, Emil Lask.) In plaas van die idee van menslike outonomie, onderskei Vollenhoven tussen God (die Wetgewer), sy skepping en sy wette vir die geskapene, insluitend sy norme vir die kenaktiwiteit. Saam daarmee word die rol van die kenner, wat in die neo-Kantiaanse denke oorbeklemtoon is, ook gerelativeer. Die klem op die self (kenner) word dus by Vollenhoven verminder en die klem op die (kenbare) wêreld vergroot, terwyl albei deur vaste godgegewe norme bepaal word.

Vanaf 1923 neem Vollenhoven afstand van sy skolastieke agtergrond en bied hy 'n alternatief vir sy vroeëre kritiese realisme, naamlik ' $n$ korrekte soort realisme van wetskringe en die realiteit van die geskape dinge waaraan verskillende modaliteite onderskei kan word. Die skepping is dus nie slegs 'sin' nie.

\section{Dooyeweerd vanaf ongeveer 1923-1928}

Vanaf ongeveer 1923 tot waarskynlik 1928 was Dooyeweerd sterk onder die invloed van Kuyper, wat tot 'n groot mate nog semiskolasties gedink het. Dooyeweerd is toe sterk aangetrek deur die semimistieke idee dat die menslike hart, anders as sy liggaam, iets transendents, iets ewigs, sou wees.

Na 1923 noem hy sy filosofiese metode 'n 'transendentale kritiek'. Dit is 'n kritiese filosofie, want dit gaan vir hom nog steeds om die noodsaaklike voorwaardes vir teoretiese kennis. Terselfdertyd is dit egter ook transendentaal, omdat dit oor die laaste Oorsprong van die denke gaan. Uit die Oorsprong ontspring die kosmiese diversiteit ('n afdalende, divergerende proses), maar in dieselfde Oorsprong kom die diversiteit ook weer saam ('n opstygende, konvergerende rigting) - 'n soort monargianistiese patroon van denke soos dit reeds hierbo deur Steen en Taljaard gesuggereer is. Die bo-tydelike hart fungeer as 'n soort sekondêre sentrum, omdat dit enersyds die beeld van God (die Oorsprong) dra, en andersyds ' $n$ intermediêre saamtrekpunt van die res van die kosmiese verskeidenheid is.

Vollenhoven en Dooyeweerd het dus op verskillende maniere die kritiese realisme vaarwel toegeroep. Vollenhoven het die besluit eerder geneem, terwyl hy bly vashou het aan 'n korrekte soort realisme, wat aan die kosmiese dinge ' $n$ vandie-bewussyn-onafhanklike realiteit toegeskryf het (vgl. Vollenhoven 2005a:110). Intussen het Dooyeweerd oorgegaan tot sy transendentale kritiek. (Oor sy transendentale kritiek is alreeds heelwat geskryf, bv. Brummer 1961 en Choi 2000.)

Ooreenkomste is moontlik tussen sy transendentale kritiek en die leer van 'n immanente logiese objek. Volgens laasgenoemde kom die kenbare werklikheid as indrukke in die menslike bewussyn, word dan as 'Gegenstande' intensioneel beskou en/of stel hulleself op fenomenologiese wyse bekend (vgl. hieronder oor Husserl).

\section{Samevatting}

Tol (2011a) vat die resultate van die verskille in bogenoemde ontwikkeling van Vollenhoven en Dooyeweerd soos volg saam:

In short, Vollenhoven came to reduce the emphasis on the self and centre his thought in the reality of law and law-spheres, i.e. the law-subject distinction, implying (normative) law as a boundary. Dooyeweerd increased the emphasis on the self in reducing its attention for the world and by situating the self in a supra-temporal environment that overviews the world as meaning. (bl. 5) 
Vanuit die bo-tydelike hart (wat hy in die plek van die rede plaas) wou Dooyeweerd in 'n sekere sin dus die kosmos oorsien.

\section{Dooyeweerd se tweede fase (1923-1928) vervolg - meer besonderhede}

Die meeste vroeëre en latere navorsers is dit eens dat Kuyper (1837-1920) 'n baie groot invloed op Dooyeweerd se denke gehad het (vgl. Young 1952:42 e.v.; Zylstra 1975:17, 18; Wolters 1985:2-10 en Chaplin 2011:27-28). Laasgenoemde skrywer (Chaplin 2011:28) meld tereg dat die groot invloed van Kuyper veral in Dooyeweerd se vroeëre publikasies duidelik is (vgl. Dooyeweerd 1937 \& 1939). Ook Henderson (1994), wat oor Dooyeweerd se vroeër denke (1918-1928) skryf, wys op die groot invloed van Kuyper se denke. (Vir die spesifieke invloede van Kuyper kan verwys word na Wolters 1985:2-10 en Glas 2011b:31.)

\section{Semimistiek by Kuyper}

Kuyper was 'n invloedryke denker. Vir sy bydraes op verskillende lewensterreine, sy geskrifte (in Engels), sy wêreldwye invloed tot vandag toe, die redes daarvoor asook die hooftrekke van sy reformatoriese lewensvisie bied Van der Walt (2010a \& 2010b) inligting vir die leser wat vinnig op hoogte van Kuyper se denkwêreld wil kom. Twee ander werke van belang, is Stellingwerff (1987 \& 1990). Van Kuipers (2011) het onlangs 'n nuwe volledig geannoteerde bibliografie van Kuyper se nalatenskap verskyn wat toegang tot sy geskrifte vergemaklik.

Volgens Vollenhoven (aangehaal in Bril 1982:102-104), Vander Stelt (1973) en Klapwijk (1980:530-542) was Kuyper (in ooreenstemming met onder andere Augustinus en Calvyn) 'n semimistieke denker. Dit blyk veral uit Kuyper $(1908,1912$ \& 1997) se meditasies baie duidelik.

Kuyper het (soos ook sommige van die teenswoordige gereformeerde denkers) nie mistisisme nie, maar mistiek voorgestaan. Daarmee bedoel hy heel waarskynlik dat hy nie 'n volledige soort mistiek wil aanhang nie. Volledige mistiek, wat gewoonlik in monistiese denke wortel (erken net een syn of werklikheid), leer dat die hele mens (liggaam en siel) van goddelike afkoms is en weer met die godheid moet verenig. Dit kon Kuyper as Christendenker nie aanvaar nie.

Semi-mistiek wortel egter gewoonlik in 'n dualistiese ontologie van 'n transendente God en 'n nie-transendente skepping. Die mens besit in die hoogste deel van sy siel (omdat dit van God afkomstig sou wees) ook iets goddeliks. Dit keer ná die dood na God terug, maar die mens kan ook reeds in hierdie lewe na 'n mistieke (ontiese) eenwording met Hom streef.

Hoewel die (semi)mistiek tot vandag nog selfs deur gereformeerde denkers as 'n bybelse gedagte verdedig word (vgl. Van Schaik 2005), beskou reformatoriese filosowe soos Vollenhoven, Popma, Mekkes en andere dit as van pagane oorsprong en dat dit groot gevare vir die Christelike geloof inhou (vgl. Van der Walt 2011:278-281). Vollenhoven beklemtoon tereg dat daar 'n grens tussen God en sy skepping is en dat die mens ('n deel van die skepping) dus onder hierdie grens staan en niks goddeliks besit nie.

\section{Semimistiek by Dooyeweerd}

Dooyeweerd meld op verskeie plekke (vgl. Henderson 1994:113-115) hoe hy in 1923 sekere van Kuyper se (semimistieke) meditasies gelees het en dat dit 'n keerpunt in sy denke veroorsaak het. Hy het toe die menslike hart as bron van die uitgange van die lewe ontdek. Reeds op die eerste bladsye van die eerste deel van sy hoofwerk (Dooyeweerd 1953:v) maak hy melding van sy ontdekking van die '... central significance of the "heart", repeatedly proclaimed by Holy Scripture to be the religious root of human existence.' Dit was egter 'n semimistieke hart!

Steen (1983:229) skryf: 'If Kuyper is to be called semi-mystic, then Dooyeweerd cannot escape this qualification either, since he is almost identical to Kuyper on these points.'

Velema (1957:238) toon later 'n verband aan tussen Kuyper en Dooyeweerd wanneer hy skryf: 'Een dergelijke struktuur [as by Kuyper] vinden wij ook by Dooyeweerd, wanneer hij spreekt van de boventijdelijke religieuse wortel der schepping.'

Popma sien ook 'n duidelike verband tussen die mistieke denke van Kuyper en Dooyeweerd se filosofie. By albei word die historiese tyd deur 'n synstekort getipeer en mistieke tyd deur synsvolheid. Dooyeweerd se 'bo-tydelike liggaam van Christus' is verwant aan Kuyper se 'mistieke liggaam van Christus' (Popma 1962:241-243).

Popma (1962:244-5) kritiseer ook Dooyeweerd se standpunt oor geloofsfunksie wat impliseer dat geloof iets transendents is as gevolg van '... its immidiate relatedness to the transcendent root and the origin of temporal existence'. Popma sê daarvan dat '... de voorstanders van een gereformeerde mystiek zich met volle reg kunnen beroepen op citaten uit [Dooyeweerd se] De Wijsbegeerte der Wetsidee en A new critique'. Popma (1962:245) sê verder: '... in Dooyeweerds geloofsfunctie-idee zit een mogelijk nog taaier rest mystiek' (as by skolastieke gereformeerde denkers).

Ten slotte het Friesen (vgl. Strauss 2004) onlangs ook mistieke denke by Dooyeweerd gesuggereer, hoewel vanuit 'n ander oord as Kuyper. Bowendien vind Friesen die mistieke trek by Dooyeweerd ook nie verkeerd nie, maar aantreklik!

\section{Positiewe invloede van Kuyper}

Behalwe hierdie minder goeie skolastieke invloed van Kuyper (vgl. Zuidema 1972), was daar ook 'n reformatoriese element wat Dooyeweerd sterk aangetrek het.

In hoofstuk 5 van sy nog ongepubliseerde manuskrip behandel Vander Stelt (2012) Kuyper breedvoerig. Hoewel hy nie daarin die lyne na Dooyeweerd deurtrek nie, staan die volgende punte van Kuyper se meer reformatoriese denke - wat Dooyeweerd ook moes geïnspireer het - duidelik uit. 
God se ryk is wyer as net die kerk: In die eerste plek het Kuyper nie langer die Christelike lewe met die kerklike vereenselwig nie, maar die betrokkenheid van Christene as koninkryksburgers op alle terreine bepleit en ook aangedui hoe so iets moontlik is. Dit was 'n reuse stap vooruit, aangesien die Protestantse Christendom vir byna drie eeue lank (na Dordt) steeds meer die Christelike geloof tot die geestelike en persoonlike lewe en kerklike en teologiese probleme beperk het, sodat hulle weinig invloed op die krisisse in die Westerse samelewing en kultuur gehad het. In sy latere boeke soos De gemene gratie (3 dele) en Pro Rege (3 dele) beklemtoon Kuyper, teenoor sy vroeëre tendens tot c. 1885 van wêreldontvlugting, dat Christene navolgers van Christus op alle terreine van die samelewing behoort te wees, want $\mathrm{Hy}$ is oor elke sentimeter van die skepping Koning. Om dit te bereik, beklemtoon Kuyper die belangrikheid van 'n Christelike lewensvisie en filosofie asook Christelike organisasies en instellings.

God se drievoudige openbaring as norm: In die tweede plek toon Kuyper aan dat die norm vir alle Christelike aktiwiteite God se openbaring is. Hy beperk hierdie openbaring egter nie - soos sy voorgangers op biblisistiese wyse gedoen het - tot net die Skrif nie. God openbaar Homself in die skepping, in die Skrif en finaal in die vleesgeworde Woord, Jesus Christus. God se openbaring in die Bybel staan dus nie geïsoleerd van ons menslike ervaring in ' $n$ bepaalde tyd en omstandighede nie. Sy drieërlei openbaring vorm 'n eenheid. Dit het ook nie net betrekking op 'n mens se persoonlike en/of geestelike lewe nie. Dit sou beteken dat die grootste deel van die lewe van minder belang is en ' $n$ soort tydelike steierwerk is wat maar vaarwel gesê kan word wanneer die ewige lewe by die dood aanbreek.

Die fundamentele rol van geloof: 'n Derde belangrike perspektief was Kuyper se opvatting oor geloof as iets fundamenteels. Op grond hiervan was dit vir Christene moontlik om hier en nou, coram Deo (voor die aangesig van God) te lewe in alles wat hulle dink en doen. Hy verwerp die gedagte dat geloof 'n genadige bykomstigheid (donum superaditum) is en nie wesenlik tot die mens behoort nie. Dit is volgens hom nie moontlik om nie (in iets) te glo nie. Daar bestaan dus nie so iets soos nie-gelowiges nie, maar wel ongelowiges. Alle mense besit (struktureel) ' $n$ 'formele' geloofsvermoë. (Dooyeweerd het dit later 'n funksie of modaliteit genoem.) Die religieuse rigting van mense se geloof kan egter verskil - in gehoorsaamheid aan God se openbaring of nie - en hierdie uitgangspunt bepaal 'n mens se totale doen en late.

'n Nuwe visie op teologie: Kuyper het vierdens ook duideliker as sy voorgangers (selfs Bavinck) tussen Christelike geloof (iets voorwetenskapliks en basies) en teologie ('n feilbare wetenskap) onderskei. Teologie is vir hom nie langer die koningin van die wetenskappe nie. Dit het nie die monopolie op God se Woordopenbaring nie en besit ook nie bonatuurlike gesag nie. Teologie word nie sonder 'n (implisiete of eksplisiete) filosofiese totaalvisie op die werklikheid beoefen nie.
Al vier hierdie skriftuurlike gedagtelyne loop vanaf Kuyper deur na Dooyeweerd en ook na Vollenhoven.

\section{Dooyeweerd se wetsidee}

Behalwe om oor die struktuur (ontologie) van die kosmos (wat tot 'n bepaalde tipe filosofie lei) te besin, moet elke denker ook oor die normatiewe rigting (dit wat behoort) besin ('n bepaalde wetsidee soos deur 'n spesifieke filosofiese stroming voorgestaan). Hierdie artikel handel hoofsaaklik net oor Dooyeweerd se tipe denke.

Dooyeweerd noem sy filosofie (vgl. veral sy vroeëre artikels vanaf ongeveer 1924 in Anti-revolutionaire staatkunde, asook Dooyeweerd 1935, 1:34 e.v.) die 'Wysbegeerte van die wetsidee'. Hierdie idee speel 'n belangrike rol in sy denke en behoort volledigheidshalwe die nodige aandag te kry. Dooyeweerd bou sy filosofie in genoemde bronne op die idee van God se soewereiniteit oor alles en hy beskou die wet dus as 'n grens tussen God en sy skepping. Dit wil lyk asof hy gedurende sy tweede fase (met prysgawe van die kritiese realisme van die eerste fase) 'n meer skriftuurlike visie op God se wet bereik. Volgens Tol se drie fases begin Dooyeweerd se derde (monargianistiese) fase egter reeds ongeveer 1928.

Daar is onbeantwoorde vrae, byvoorbeeld of daar ook in Dooyeweerd se wetsidee verskuiwings gekom het en indien wel, wat die verband tussen sy tipologiese veranderings (in drie fases) en die betrokke wetsidee is. Die omgekeerde kan egter ook gevra word, naamlik of 'n nuwe wetsidee dalk sy tipe filosofie beïnvloed het.

\section{Beïnvloeding van buite die eie geesgenootlike kring}

Behalwe die invloed van geesgenote soos Kuyper moet tegelykertyd ook rekening gehou word met die neo-Kantiaanse of neo-idealistiese beïnvloeding waarop alreeds hierbo en ook deur talle skrywers (bv. Brümmer 1961:13 e.v. en Wolters 1985:10 e.v.) gewys is. Dooyeweerd (1953:v.) erken hierdie feit ook self: 'Originally I was strongly under the influence first of the Neo-Kantian philosophy, later of Husserl's phenomenology'. Dit was die modefilosofie van destyds en Henderson (1994) toon die invloed daarvan reeds by Dooyeweerd vóór 1928 aan (d.w.s. in sy tweede fase). Dooyeweerd was veral in die kenteorie geïnteresseerd. Die fokuspunt van die neo-idealistiese denkers was ook die vraag hoe 'n mens betroubare wetenskaplike kennis kan bereik.

Met twee standpunte gekonfronteer: Henderson (1994:182) en Steen (1983:14-20) poneer dat Dooyeweerd in sy vroeëre ontwikkeling met twee standpunte gekonfronteer is (soos alreeds hierbo gestel). Gedurende die eerste fase in sy denke aanvaar Dooyeweerd, aan die een kant, die kritiese realisme van die gereformeerd-skolastieke tradisie van sy geesgenote. Hiervolgens het die logosleer (van Woltjer e.a.) gesorg dat daar ooreenstemming tussen die menslike verstand en die objekte van kennis in die werklikheid sou wees. Dooyeweerd voel egter later dat die logosleer tot 'n Platoniese verdubbeling van die werklikheid lei. Hy vind ook nie vrede met die idee dat kennis net 'n ooreenstemming tussen denke en syn is nie, 
dit wil sê dat kennis 'n blote duplikaat van die werklikheid is nie. Sy kritiese realisme bevredig dus nie werklik nie.

Aan die ander kant kon Dooyeweerd egter ook nie die neo-idealistiese kenteorie volledig aanvaar nie. Terwyl die realisme eensydig die meeste klem op dinge (kenobjekte) gelê het, het die neo-idealisme van die neo-Kantiaanse skole (bv. die Freiburgse of Badense en Marburgse skole) die kenner self (die subjek) beklemtoon. Soos by alle rasionalistiese denkers is die wet (normatiewe riglyne) geaprioriseer, dit wil sê van buite na binne die verabsoluteerde rede geplaas. Dooyeweerd se kritiek op hulle was dat die werklikheid (as iets bloot logies) in die rede verdwyn of geabsorbeer word. Volgens hom het hierdie idealiste hulle greep op die werklikheid verloor. Selfs God het bloot 'n produk van die menslike rede geword!

In die tweede plek kon Dooyeweerd beslis nie die neoidealistiese idee aanvaar dat die menslike denke outonoom kan wees nie. Hiervolgens wil die mens sy eie norme bepaal in plaas daarvan om aan eksterne norme onderworpe te wees. Dooyeweerd kies God as Skepper en Wetgewer en ook die oorsprong van die norme vir die logiese kenaktiwiteit. Dooyeweerd vervang dus die neo-Kantiaanse outonomie met teonomie.

Dooyeweerd se oplossing: Die integrasie van die kenner en die kenbare (die subjek en die objek soos dit destyds genoem is) vind Dooyeweerd vanaf ongeveer 1923 in die menslike hart, wat hy na aanleiding van die meditasies van Kuyper weer na vore bring (vgl. Henderson 1994:114, 115). Vir Dooyeweerd kwalifiseer nie die rede nie, maar die hart die mens en dit is ook die sentrum van denke, wil, gevoel, ensovoorts. Dooyeweerd vervang dus die verabsoluteerde rede met 'n bo-tydelike hart (vgl. Henderson 1994:115).

\section{Dooyeweerd (1953) skryf:}

He [God] has expressed His image in man by concentrating its entire temporal existence in the radical religious unity of an ego in which the totality of meaning of the temporal cosmos was to be focused upon its Origin. (bl. 55)

Henderson (1994:182) se konklusie is dat hierdie twee stromings by Dooyeweerd (die neo-Calvinistiese en neoKantiaanse)'... can not be traced to simply the one or the other, but were involved'. Die leser word ook steeds getref deur die sterk (neo-)Kantiaanse kleur van sy denke. (Vgl. Hart 2000:125 e.v. wat nog sterk rasionalistiese trekke in Dooyeweerd se idee van wet/orde uitwys.) Net soos Kant (ou idealis) en die neo-Kantiane (neo-idealiste) fokus Dooyeweerd ook op die kenteorie, op die moontlikhede en voorwaardes vir wetenskaplike denke (d.w.s transendentale kritiek).

\section{Dooyeweerd se derde, monargianistiese fase (1928-1977)}

Aangesien Vollenhoven en sommige van sy navolgers Dooyeweerd veral as monargiaanse denker beskou, word voorts daarop gekonsentreer. Wat hou dit presies in? Wie was die vorige verteenwoordigers daarvan? Hoe verskil dit van Dooyeweerd se voorafgaande semimistieke konsepsie?

\section{'n Kort sistematiese beskrywing}

Vollenhoven onderskei (in sy 'privatissima') eers vanaf 1973 'n monistiese monargianisme naas die dualistiese tipe. (Sommige standpunte wat hy eers as dualistiese monargianisme of as semimistiek aangedui het, tipeer hy nou as monistiese monargianisme.) Vir besonderhede kan Vollenhoven (1979), Bril (1982:63-68, 118-120; 1986:153-163; 2000:336-340) en Tol (aangehaal in Vollenhoven 1979) geraadpleeg word.

Monisties en dualisties: Volgens Vollenhoven se terminologie aanvaar 'n monistiese filosofie die oorspronklike eenheid van alles waaruit die verskeidenheid dan ontspring. Dit vorm as 't ware die teenpool van 'n dualistiese ontologie wat beweer dat daar oorspronklik ' $n$ dualiteit of tweeheid bestaan het - gewoonlik die hoëre of transendente en die laere of nietransendente genoem.

Monargiaans: Monargianisme (van die Griekse monarches wat alleenheersend beteken) dui op 'n hoogste godheid of alleenheerser heel bo aan die synshiërargie of synspiramiede. Daaronder volg 'n nie-transendente, maar universele denkgees (nous), iets goddeliks maar tog nie gelyk aan die godheid (monarg) self nie. Heel onderaan die piramide van syn is die mens, wat uit psyche [gees] en soma [liggaam] bestaan. Die individuele, natuurlike mens se gees is (by die dualistiese monargianisme) nie uit sigself tot aksie in staat nie. Dit word egter van tyd tot tyd deur die universele 'nous' geaktualiseer of in beweging gebring. (Vir besonderhede vgl. Vollenhoven aangehaal in Bril 1982:63, 79, 94 e.v.; Bril 2000:339 en Vollenhoven 2011:125, 126 e.v.)

Twee hooftipes monargianisme: Soos reeds vermeld, onderskei Vollenhoven twee hooftipes (met verskillende subtipes) by hierdie denkrigting, naamlik 'n dualistiese (sedert 1973) en ook'n monistiese (vgl. Bril aangehaal in Vollenhoven 2000:22-28, 335-336). Laasgenoemde vorm daarvan word onder andere aangetref by die Griekse denker Speusippos (410-339 v.C.), Plotinos (205-270 n.C.), die Renaissance-denker, Cusanus (1401-1464) en die rasionalistiese denker Husserl (1859-1938).

By die dualistiese monargianisme is die godheid (God in die Christelike denke) die Onbeweeglike Beweër, wat as objek van begeerte die laere kosmiese werklikheid in beweging sit, sodat dit kan terugstrewe na die hoëre doel of godheid. By die monistiese tipe is god of God egter die Regeerder (Ruling One) of 'Werkende Syn', wat die laere in beweging bring. (Vir laasgenoemde tipe vgl. Vollenhoven 1979; Vollenhoven aangehaal in Bril 1982:62-68, 118-120; Bril 1986:375; Bril aangehaal in Vollenhoven 2000:22-28, 335-336; Vollenhoven 2005a:264; 2011:117-155.)

\section{'n Oeroue dualisties-monargiaanse tradisie}

Die monargianistiese werklikheidsvisie kom moontlik reeds by die Griekse denker, Aristoteles (384-322 v.C.) in sy latere ontwikkelingsfases voor. 'n (Noölogiese) soort monargianisme word egter reeds by Alexander van Afrodisias (c. 200 n.C.) aangetref (vgl. Vollenhoven 2011:274 vir'n grafiese voorstelling), sodat dit later as Alexandrisme bekend staan. 
Hierdie heidense gedagte oor 'n godheid word egter vanaf die vroeg-Christelike denke al met die bybelse godsidee verbind en loop deur die Middeleeue tot vandag toe. (Die bekende middeleeuse denker, Thomas van Aquino, het byvoorbeeld aanvanklik [monisties-] monargiaans gedink en eers later na 'n subsistensieteorie oorgegaan.)

Monargianistiese denkers ontken volgens hierdie soort filosofie meestal die drie-eenheid van God en staan in die kerkgeskiedenis bekend as die antitrinitariërs of unitariërs (vgl. Polman 1960). Hulle is dus as ketters beskou (vandaar waarskynlik ook Thomas se verandering van standpunt). Volgens 'n ou dekreet van Theodosius die Grote (395 n.C.) het loënaars van die Drie-eenheid destyds die doodstraf verdien. Om hierdie rede sterf ook die unitariër, Servet, byvoorbeeld op die brandstapel in Genève in die tyd van Calvyn.

Hoewel hierdie vervolging volgens vandag se maatstawwe nie moes plaasgevind het nie, het die Roomse en Protestantse kerke van destyds tog duidelik ingesien hoe gevaarlik die monargianisme was. By bepaalde tipes van hierdie tradisie is die aktiwiteit van die individuele mens heeltemal afhanklik van die impulse van die universele denkgees. 'n (pneumatologiese) Monargianistiese visie (vgl. Vollenhoven 2011:274) lei dus tot quiëtisme, passiwiteit, gelatenheid en hiperlydelikheid by die mens (vgl. ook Vollenhoven 2005a:345-346; Bril 2000:360). Indien dit so is dat die goddelike, alleenwerksame en alleenheersende gees (herdoop tot die God van die Bybel onder Christelike sintesedenkers) alles in die mens werk, is menslike berou, vreugde, ensovoorts slegs sý werk. Berou het dus eintlik geen sin meer nie, aangesien dit slegs 'n uitloper van die goddelike aktualisering is. Die mens word op hierdie wyse van 'n eie verantwoordelikheid onthef - die mens wil nie, kan nie en deug nie. Monargianisme is dus 'n onbybelse en ongereformeerde denkwyse oor sowel God as die mens en hulle onderlinge verhouding.

\section{Monistiese monargianisme: Enkele historiese verteenwoordigers}

Soos reeds genoem, vermoed Vollenhoven die volgende historiese lyn: Speusippos - Plotinos - Cusanus - Husserl Dooyeweerd. Hierdie artikel word beperk tot slegs enkele van Dooyeweerd se veronderstelde voorgangers en veral tot Plotinos.

Plotinos (205-270): Die monistiese monargianistiese tradisie in die filosofie word soms ook die henologiese tradisie genoem. Dit is afgelei van die Grieks hen [een] wat duidelik op die monistiese aard daarvan dui. Volgens Plotinos gaan die hen [ene] of godheid alle syn te bowe. Die wêreld se verskeidenheid emaneer of kom trapsgewys uit die godheid as die oorspronklike eenheid voort. 'n Mens sou dit die tipiese monargianistiese 'van bo na onder'-denke kon noem.

Wat die mens betref, aanvaar Plotinos ' $n$ bo-tydelike, onsterflike sielsdeel. Die mens kan homself in sy eie siel, in sy Seelengrund of Seelenspitz verdiep. (Duits: Selbstversenkung). As gevolg van die feit dat die monistiese denke 'n synshiërargie aanvaar en daar geen radikale onderskeid of grens tussen die godheid en die mens is nie - eersgenoemde is slegs hoër as laasgenoemde - ontdek die mens in die diepte van sy eie siel die goddelike (Innerschau). In ekstase word die mens dan een met god (unio mystica). Hierdeur word hy verhef (Erhebung) 'bo' die wêreld om in plaas van die veelheid daarvan, die oorspronklike eenheid (godheid) raak te sien (Einheitschau). Hierdie is die ontiese 'van onder na-bo'-denke.

Volgens 'n eeue oue voorafgaande tradisie - al bekend in die Griekse filosofie - is Plotinos se hen of godheid die ewige. Daarteenoor staan die kosmiese werklikheid as die tydelike of verganklike. Tyd (teenoor eenheid) is 'n vorm van verdeeldheid of verskeidenheid, fragmentering wat uit die ewige eenheid voortkom. Dink aan die voorbeeld van 'n prisma wat (wit) lig (die ewige) in allerlei kleure (die tydelike) opbreek. Geertsema (1970:151) wys op 'n onmiskenbare relasie tussen hierdie tydsidee van Plotinos en dié van Dooyeweerd later. Vollenhoven (vgl. Bril 1982:63) noem Speusippos die eerste transendentalis.

Alle kosmiese dinge is egter nie tydelik van aard nie. Soos reeds gesê, aanvaar Plotinos dat die psychai van mense op byna dieselfde niveau as die godheid bestaan, dit wil sê bo die tyd.

Cusanus (1401-1464): ' n Leermeester van Cusanus, Heymeric van de Velde (a Campo in Latyn), leer ook soos Plotinos dat alle kosmiese dinge trapsgewys uit God emaneer of stroom en weer na hom terugstreef (reversio). 'n Mens moet dus by selfkennis begin, omdat die mens se intellek 'n spieël van al die bestaande dinge is. Dit lei ook tot Godskennis, aangesien die mens in die hoër deel van sy intellek onties aan God verwant is. Van de Velde gebruik ook reeds die term 'coincidentia oppositorum' (die saamval van teenstellings).

Hierdie gedagte kom duidelik weer by Nicholas van Kues of Cusa (gelatiniseerd as Cusanus) na vore (vgl. Bril aangehaal in Vollenhoven 2000:109 asook Wikipedia vir die werke van en oor Cusanus). Die godheid beteken die eenheid bo alle (kosmiese) verdeeldheid, die opheffing van alle eindige, tydelike teenstellings. Daarom verkondig hy 'n docta ignorantia (leer van onwetendheid) of 'n negatiewe teologie as die enigste manier om God te ken. ('n Mens kan daarvolgens net sê wat God nie is nie.) 'n Mens vind by Cusanus dus weer die dubbele beweging van Erhebung (die mistieke rigting van onder na bo, na die Eenheid) en 'n gevolglike Einheitschau, asook die omgekeerde idee van die tydelike as 'n 'versplintering' van die ewige (dit wil sê die rigting van bo na onder).

Husserl (1859-1938): Volgens Vollenhoven loop hierdie gedagtegang deur tot by Edmund Husserl. By laasgenoemde onderskei Vollenhoven 'n ontwikkelingsgang (vgl. ook De Boer 1968, 1977) in drie fases wat egter nie hier verder bespreek sal word nie (vgl. Vollenhoven 2005a:190).

Soos alle laat-rasionalistiese denkers het Husserl groot klem op wetenskaplike metodes gelê om tot ware kennis te kom. Tipies idealisties probeer hy ook 'n versoening bewerk tussen die teoretiese rede (natuurwetenskaplike metodes) en die praktiese rede (geesteswetenskaplike metodes). Bo 
alles was hy egter 'n rasionalis, (vgl. Son 1972:59 e.v.) wat in die bestaan van die rede ('n verabsoluteerde, outonome selfregverdigende verstand) geglo het. Sy filosofie bied dus 'n transendentale kritiek - 'n beskrywing van die voorwaardes vir die bestaan van die rede of bewussyn en sy werking. Die aprioriese inhoude van die bewussyn ondersoek hy (net soos Scheler) met sy fenomenologiese metode van wesenskou.

'n Kort vergelyking met Thomas van Aquino en Husserl lewer die volgende op. Dooyeweerd se denke is aan Thomas se eerste, monisties-monargiaanse konsepsie verwant. Later verander Thomas egter na 'n subsistensieteorie sonder 'n immanente logiese objek. 'n Latere subtipe van die teorie word by ' $n$ hele reeks denkers gevind (vgl. Vollenhoven 2005a:403), waaronder ook Husserl, naamlik met 'n immanente logiese objek aan die tema van 'n intensionele akte verbind. By Husserl verloor die buitewêreldse gevolglik sy realiteit, terwyl dit ook by Dooyeweerd (finale fase) slegs sin het.

In alle geval vermoed Vollenhoven (aangehaal in Bril 1982: 105-109, 118-120 en Bril aangehaal in Vollenhoven 2000:247, 259) en ook Verburg (1989) 'n duidelike invloed van Husserl se tipe monargianisme op Dooyeweerd.

\section{Dooyeweerd as monargiaan}

'n Mens vind inderdaad ook by Dooyeweerd altwee bogenoemde rigtings waarop reeds herhaaldelik gewys is. In die eerste plek 'n neerdalende, divergerende rigting van die Oorsprong (as eenheid) na benede (die kosmiese verskeidenheid), en in die tweede plek 'n opstygende, konvergerende rigting van die kosmiese verskeidenheid na 'n eenheid in die Oorsprong (God).

Vanuit 'n bo-individuele denkgees (nie baie duidelik identifiseerbaar in Dooyeweerd se geval nie) vind daar aktivering na ondertoe plaas - dink aan Dooyeweerd se vier religieuse (geestelike, maar misterieuse) grondmotiewe wat die Westerse beskawing sou aangedryf het en nog steeds doen. Omgekeerd is die tydelike werklikheid (temporalitas) via die bo-tydelike menslike hart (aevernitas) op die ewige Oorsprong (aeternitas) gerig.

Terloops, in hierdie opsig bestaan by Dooyeweerd (net soos by Husserl) weer ' $n$ merkwaardige ooreenkoms met die denke van Thomas van Aquino (1224/1225-1274). Laasgenoemde huldig ook eers 'n monistiese monargiaanse filosofie. Soos Aertsen $(1974,982)$ dit beskryf, was 'n kerngedagte by Thomas ook die sirkulasiemotief, naamlik dat die laere skepping uit die ewige God (Oorsprong) voortvloei, terwyl dit ook weer tot God (as die hoogste Doel daarvan) terugkeer. Ook Dooyeweerd se idee van 'n aevum (bo-tydelike sentrum in die mens) kom reeds by Thomas voor en word deur Dooyeweerd (1940:181, voetnote 23 en 24) sonder kritiek oorgeneem.

\section{Dooyeweerd se bo-tydelike hart}

Binne hierdie monistiese monargianistiese werklikheidsbeskouing word Dooyeweerd se idee van 'n bo-tydelike hart dus duideliker. Hierop het hy baie kritiek ontvang (vgl. slegs Wiskerke, 1962a; 1962b). Die menslike hart is vir Dooyeweerd die saamtrekpunt wat die bo-tydelike eenheid van die skeppingsverskeidenheid waarborg en op die Oorsprong van alles rig. Vir Dooyeweerd trek die hele skepping antroposentries in die mens saam. Henderson (1994:200) noem dit die switch board [skakelbord] waarin al die fasette van die skepping verteenwoordig is, maar hy beskou dit as 'n troublesome idea [hinderlike idee] by Dooyeweerd.

In ooreenstemming hiermee is God vir Dooyeweerd dus syn terwyl die skepping slegs $\sin$ (meaning) is, omdat dit van God afhanklik is en ook na Hom terugwys. Dit kan dus nie betekenis en/of sin in sigself hê nie. Op die oog af klink dit na 'n bybelse gedagte (vgl. Rom 11:36), maar dan moet dit in 'n religieuse en nie in 'n ontiese sin verstaan word nie.

Verloor die skepping op hierdie wyse nie dalk sy konkreetheid nie? Glas (2011a:14-16; 2011b:31, 32) merk op dat die begrip sin (betekenis) by Dooyeweerd moeilik verteerbaar is. Immers, hoe kan iets uit God voortkom en in Hom opgaan sonder om self iets te wees? Was Dooyeweerd se idee van sin nie moontlik 'n oorreaksie teen die skolastieke substansieidee (d.w.s. dat die menslike siel selfstandig bestaan en kan voortbestaan) nie?

Soos reeds hierbo by Husserl gesuggereer, verloor die wêreld buite die menslike denke sy konkrete bestaan en kan dit slegs deur 'n redelike akte gekonstitueer en bestudeer word. Is Dooyeweerd se idee van die kosmiese werklikheid as blote sin nie dalk nog 'n duidelike eggo van die Husserliaanse filosofie nie?

\section{Die verskille en ooreenkomste tussen monistiese monargianisme en die semimistiek}

Dit is belangrik om ten slotte na te gaan hoe die tweede (semimistieke) fase by Dooyeweerd verskil, maar tog aansluit by sy derde monisties-(monargianistiese) periode.

Verskille: Die belangrikste verskil tussen die monistiese monargianisme en die semimistiek is dat eersgenoemde 'n monistiese konsepsie is (alle verskeidenheid kom voort uit die primêre eenheid), terwyl laasgenoemde by 'n dualistiese filosofie inpas ('n oorspronklike tweeheid van 'n transendentewige en 'n nie-transendent-tydelike werklikheid word van die begin af onderskei). Ek verwys hier graag na Vollenhoven (2005a:377-380) se insiggewende uiteensetting oor die semimistieke denke deur die eeue.

Die dualistiese karakter van die semimistiek beteken egter nie dat dit op dieselfde standpunt as die dualistiese monargianisme neerkom nie. By laasgenoemde konsepsie is daar ' $n$ fundamentele grens tussen die godheid en die goddelike universele denkgees of wêreldsiel. Die monistiese monargiaan (vgl. die vroeëre opmerking dat die verhouding van die universele denkgees tot God by Dooyeweerd onduidelik is) en die semimistikus erken nie so 'n prinsipiële grens nie - ook nie een tussen die kosmos (nie-transendente) en die godheid en/of God (die transendente) nie. Hierdie grens kom binne die mens self voor, want hy beskik oor 'n hoëre, transendente faset, die hoogste deel van sy menswees. 
In die semimistiek word meestal ook 'n trigotomistiese antropologie gehuldig. Die mens bestaan naamlik uit liggaam, siel en gees, waarvan slegs laasgenoemde transendent en dus onsterflik sou wees. In die monistiese monargianisme word die hoogste deel in die mens die 'sielsgrond' of 'sielspits' genoem, wat as bo-tydelik en dus onsterflik beskou word.

Ooreenkomste: In die gevalle van monistiese monargianisme en die semimistiek besit die mens dus iets byna goddeliks. In al twee hierdie standpunte word ook van 'n ontologiese hiërargie met twee rigtings uitgegaan. Alles kom van God as die hoogste syn en die laere kosmiese syndes loop uiteindelik terug na die hoogste godheid en/of God. Die bybelse idee van die mens as die beeld van God word dus ook (deur Christelike denkers) as iets onties ('n goddelike, bo-tydelike deel) beskou. Anders gestel: die beeld van God dui op iets struktureels in die mens. In werklikheid dui hierdie bybelse gegewe op 'n religieuse verhouding. Die mens vertoon God se beeld in die mate waarin die skepsel God se gebooie - veral sy sentrale liefdeswet - gehoorsaam en is dus nie outomaties, as gevolg van sy strukturele samestelling, beeld van God nie (vgl. Bril 2000:278-280).

Verwantskap: Uit die voorafgaande is dit duidelik dat die monistiese monargianisme en die semimistiek, ten spyte van verskille, baie na mekaar kan lyk (vgl. Plotinos hierbo). By die dualistiese monargianisme is mistiek nie moontlik nie, terwyl die monistiese monargianisme 'n krasse vorm van mistiek (eenwording met of terugkeer tot God) impliseer.

Hiermee is die Vollenhoveniaanse perspektief op Dooyeweerd afgehandel. Dit blyk ten minste dat elke reformatoriese denker, as kind van sy eie en voorafgaande tye, nooit daarin slaag om sigself heeltemal van vreemde, selfs onbybelse invloede te ontworstel nie. Die opdrag tot semper reformanda [voortdurende reformasie] is nooit afgehandel nie! Dit geld ook hierdie poging tot ' $n$ tipering van Dooyeweerd se filosofie.

Terselfdertyd slaag elke reformatoriese denker tog ook daarin om enkele treë op die pad van 'n philosophia reformata te vorder. Dit geld ook van Dooyeweerd se denke.

\section{Hoogtepunte in Dooyeweerd se denke}

Die voorafgaande kritiese blik op Dooyeweerd se filosofie beteken nie dat dit as onbelangrik afgeskryf mag word nie. Uit sy belangrike bydrae tot die reformatoriese denke lig ek ten slotte die volgende hoogtepunte uit:

- In ooreenstemming met die lewensvisie van Kuyper het hy heelhartig die bybelse gedagte van die koningskap van Christus oor alle lewensterreine voorgestaan en ook aangetoon hoe dit teoreties begrond kon word.

- Hy het oortuigend bewys dat die werklikheid nie bloot vanuit' $n$ immanente, binnewêreldse, empiriese perspektief verklaar kan word nie. Christelike wetenskaplikes moet die wêreld vanuit die Skepper daarvan en sy openbaring beskou.
- Reformatoriese denkers behoort krities te staan teenoor alle pogings tot sintese of akkommodasie tussen God se Woord en vroeëre pagane en hedendaagse sekulêre denke.

- Die antitese tussen goed en kwaad mag nie gesoek word in 'n onderskeid tussen die strukture van die skepping nie (die kerklike lewe is nie vanselfsprekend goed en die politiek outomaties iets uit die bose nie). Goed en kwaad bestaan as gevolg van ' $n$ kontras in die religieuse rigting waarvolgens mense leef en hoe dinge in die werklikheid gevorm en gebruik word - in gehoorsaamheid of ongehoorsaamheid aan God se wet.

- Teoreties-wetenskaplike denke word deur 'n grondliggende, religieuse oorgawe bepaal en is van 'n omvattende lewens- of werklikheidsvisie afhanklik.

- Wetenskaplikes behoort aan die geskiedenis en filosofiese grondslae van hulle onderskeie vakke aandag te skenk.

- Christelike wetenskap beteken nie net 'n vroom Christelike byvoeging by die gangbare wetenskaplike resultate nie, maar ' $n$ diepgaande van-binne-uit-reformasie van elke vakgebied.

- Dooyeweerd se filosofie bied ook die analitiese gereedskap om op 'n nuwe wyse die ondersoekvelde van die vakwetenskappe te benader en op hierdie wyse onbybelse benaderings, reduksionismes en antonomieë te voorkom.

- Ten slotte het Dooyeweerd ook Kuyper se pluralistiese samelewingsfilosofie verder uitgebou en verfyn. Hy maak'n belangrike onderskeid tussen strukturele en konfessionele pluralisme. Eersgenoemde konsep impliseer die erkenning van 'n verskeidenheid menslike samelewingsverbande, elk met eiesoortige en beperkte ampte, gesag, mag en verantwoordelikhede. Laasgenoemde begrip beteken dat mense van alle geloofsoortuigings die reg behoort te hê op die totstandbrenging van hulle eie lewensbeskoulik georiënteerde instellings (bv. Christelike, Joodse, Moslem en sekulêre skole) en organisasies (bv. politieke partye en vakbonde).

Mag hierdie paar flitse en die voorafgaande ontleding van Dooyeweerd se denke lesers aanspoor om self sy geskrifte te lees.

\section{Slot: Terug- en vooruitblik}

Met 'n kort terugblik en vooruitskouing kan hierdie sowel as die vorige twee artikels afgesluit word.

\section{Terugblik}

'n Afrikaspreuk lui dat wanneer 'n mens praat (en seker ook skryf), jy daarvoor moet sorg dat jy nie net kos vir die kameelperde hoog in die boomtakke gee nie, maar ook 'n bietjie gras vir die klein steenbokkies laag op die grond. Of die voorafgaande trilogie daarin geslaag het om vir sowel die kameelperde (filosofiese fynproewers) as vir die steenbokke (gewone belangstellendes) iets te gee om te herkou, sal hulle alleen kan bepaal.

Al drie artikels was oorsigtelik en verkennend van aard. Die skrywer sou veel meer na Vollenhoven, Stoker en Dooyeweerd se eie geskrifte wou verwys. Daarom dra die trilogie 'n voorlopige karakter. Veel meer Kleinforschung is 
nodig. Daarvoor is kritiese uitgawes van al drie filosowe se werke 'n vereiste. 'n Verantwoorde rekonstruksie van die ontstaan van die reformatoriese filosofie, of selfs net van een van die driemanskap (dit het Steen, 1983:278 al van tevore besef) behels die lewenstaak van 'n hele span navorsers en nie net van een persoon nie.

\section{Vooruitblik}

Hierdie trilogie is begin met die vraag hoe ' $n$ tradisie sodanig aan 'n nuwe generasie oorgedra kan word dat dit nie 'n dooie tradisie word nie, maar 'n lewende tradisie bly. $\mathrm{Na}$ al die voorafgaande bladsye mag dit egter vir die jonger geslag nie net verwarring nie, maar ook frustrasie inhou. Soveel verskil van mening en dit net onder die drie eerste Christelike filosowe! So 'n komplekse proses waarby soveel moontlike invloede 'n rol gespeel het! Drie unieke persoonlikhede wie se denke elk iets oorspronkliks bevat en wat nie net tot eksterne invloede herlei kan word nie ...

Die volgende waarskuwing moet dus in gedagte gehou word. Die driemanskap was, soos elke geslag, kinders van hulle tyd en bowendien net feilbare mense by wie se filosofieë ons nooit mag sweer nie. Aan die een kant is diepe nederigheid gepas. Calvyn het al gesê dat die eerste, tweede en derde vereiste vir 'n ware Christelike filosofie humilitas [nederigheid] is.

Aan die ander kant het ons hier met ' $n$ besondere ryk tradisie te make wat betekenis vir die hele lewe het. Dit bevat groot potensiaal om op 'n krities-kreatiewe wyse (vgl. die inleiding tot die eerste artikel; Van der Walt 2013a) verder ontwikkel te word. Daar kan voortgebou word op die fondamente van dit wat die afgelope 75 jaar goed was; sodanig uitgebou dat dit relevant en inspirerend vir ons eie tyd en omstandighede is - 'n lewende tradisie!

\section{Erkenning}

Hierdie artikel word met opregte waardering opgedra aan $\mathrm{dr}$ K.A. Bril en dr A. Tol, twee Vollenhoven-kenners in Nederland, vir hulle advies by die navorsing vir hierdie artikel.

\section{Mededingende belange}

Die outeur verklaar dat hy geen finansiële of persoonlike verbintenis het met enige party wat hom nadelig kon beïnvloed het in die skryf van hierdie artikel nie.

\section{Literatuurverwysings}

Aertsen, J.A., 1974, 'Uit God zijn alle dingen' [Uit God is alle dinge], Philosophia Reformato 39(2), 102-155.

Aertsen, J.A., 1982, Natura et creatura: De denkweg van Thomas van Aquino, VU Boekhandel, Amsterdam.

Bril, K.A., 1982, Vollenhoven's laatste werk, 1970-1975, VU Boekhandel, Amsterdam.

Bril, K.A., 1986, Westerse denkstructuren: Een probleemhistorisch onderzoek, VU Boekhandel, Amsterdam.

Bril, K.A., 2000, 'Redaksionele bydraes', in D.H.Th. Vollenhoven, Schematische kaarten, De Zaak Haes, Amstelveen, pp. 260-422.

Brümmer, V., 1961, Transcendental criticism and Christian philosophy: A presentation and evaluation of Herman Dooyeweerd's Philosophy of the cosmonomic idea, Wever, Franeker.

Chaplin, J., 2011, Herman Dooyeweerd: Christian philosopher of state and civil society, University of Notre Dame Press, Notre Dame, Indiana.
Choi, Y.J., 2000, 'Dialogue and antithesis: A philosophical study of the significance of Herman Dooyeweerd's transcendental critique', Ph.D thesis, Faculty of Philosophy, PU for CHE, Potchefstroom.

De Boer, Th., 1968, De ontwikkelingsgang in het denken van Husserl, Van Gorcum, Assen.

De Boer, Th., 1977, 'Edmund Husserl', in C.P. Bertels \& E. Petersma (reds.), Filosofen van de 20e eeuw, pp. 87-100, Van Gorcum, Assen.

De Bruyn, J. (red.), 'Dooyeweerd herdact', Referaten gehouden op de DooyeweerdSymposium aan de Vrije Universiteit van Amsterdam op Vrijdag 18 Nov. 1994, VU Boekhandel, Amsterdam.

De Gaay Fortman, W.F., Hommes, H.J., Dengerink, J.D., Langemeier, G.E., Mekkes, J.P.A., Van Peursen, C.A. \& Stellingwerff, J., 1965, Philosophy and Christianity: Philosophical essays dedicated to Prof. Dr. Herman Dooyeweerd, Kok, Kampen.

Dooyeweerd, H., 1928, 'Het juridisch causaliteitsprobleem in 't licht der wetsidee' [Die juridiese oorsaaklikheidsprobleem in die lig van die wetsidee], Anti-Revolutionaire Staatkunde 2, 21-124.

Dooyeweerd, H., 1935, De Wijsbegeerte der westidee, 3 dele, Paris, Amsterdam.

Dooyeweerd, H., 1937, 'Wat de Wijsbegeerte der wetsidee aan Kuyper te danken heeft' [Wat die Wysbegeerte van die wetsidee aan Kuiper te danke het], De Reformatie $18(5), 63-65$, Oktober.

Dooyeweerd, H., 1939, 'Kuyper's wetenschapsleer' [Kuiper se wetenskapsleer], Philosophia Reformata 4(4), 193-232.

Dooyeweerd, H., 1940, 'Het tijdsprobleem in de Wijsbegeerte der wetsidee' [Die tydsprobleem in die Wysbegeerte van die wetsidee], Philosophia Reformata 5 , 160-182, 193-234.

Dooyeweerd, H., 1953, A new critique of theoretical thought, 4 vols., Paris, Amsterdam.

Dooyeweerd, H., 1973, 'Introduction', in K.A. Bril, H. Hart, H. \& J. Klapwijk (eds.), The idea of a Christian philosophy: Essays dedicated to D.H.Th. Vollenhoven, pp. 5-16, Wedge Publishing Foundation, Toronto.

Fernhout, H., 1975, Man, faith and religion in Bavinck, Kuyper and Dooyeweerd, Institute for Christian Studies, Toronto.

Geertsema, H.G., 1970, 'Transcendentale openheid: Over de zinkarakter van de werkelijkheid in de wijsbegeerte van H. Dooyeweerd' [Transendentale openheid: Oor die sinkarakter van die werklikheid in die wysbegeerte van H. Dooyeweerd], Philosophia Reformata 35(4), 25-56, 132-155.

Geertsema, H.G., Zwart, J., De Bruyn, J., Van der Hoeven, J. \& Soeteman, A., 1994, Herman Dooyeweerd (1894-1977): Breedte en actualiteit van zijn filosofie, Kok, Kampen.

Glas, G., 2011a, 'What is Christian philosophy? [Wat is Christelike filosofie?]', Pro Rege 49(1), 1-17, September.

Glas, G., 2011b, Twijfel, bewijs, overgave: Over christelijke filosofie, Sjibolet, Amsterdam.

Hart, H., 2000, 'Notes on Dooyeweerd, reason and order', in D.F.M. Strauss, \& M. Botting (eds.), Contemporary reflections on the philosophy of Herman Dooyeweerd, pp. 125-146, The Edwin Mellen Press, Lewiston.

Henderson, R.D., 1994, 'Illuminating law: The construction of Herman Dooyeweerd's philosophy', 1918-1928', Dissertation, Faculty of Philosophy, Free University, Amsterdam.

Hommes, H. van Eikema, 1982, Inleiding tot de wijsbegeerte van Herman Dooyeweerd, Nijhoff, 's-Gravenhage.

Ive, J., 2012, 'A critically comparative Kuyperian analysis, and a trinitarian erichoretic reconstruction of the reformational philosophies of Dirk $H$. Th. Vollenhoven and Herman Dooyeweerd', Ph.D. thesis, Faculty of Theology, Free University, Amsterdam.

Kalsbeek, L., 1975, Contours of a Christian philosophy: An introduction to Herman Dooyeweerd's thought, trans. \& ed. by B. \& J. Zylstra, Wedge Publishing Foundation, Dooyewe

Kalsbeek, L., 1983, De Wijsbegeerte der wetsidee: Proeve van een Christelijke filosofie, Buijten \& Schipperheijn, Amsterdam.

Klapwijk, J., 1980, 'Honderd jaar filosofie aan de Vrije Universiteit', in M. van Os \& W.J.'Wieringa (reds.), Wetenschap en rekenschap 1880-1980: Een eeuw van wetenschapsbeoefening en wetenschapsbeschouwing aan de Vrije Universiteit, pp. 529-593, Kok, Kampen.

Kock, P. de B., 1973, Christlike wysbegeerte: Standpunte en probleme, Bd. 1, SACUM, Bloemfontein

Kraay, J.H., 1979, 'Successive conceptions in the development of the Christian philosophy of Herman Dooyeweerd, Part 1: Contribution to a discussion' [Opvolgende konsepsies in die ontwikkeling van die Christelike filosofie van Herman Dooyeweerd, Deel 1: Bydrae tot 'n bespreking], Philosophia Reformata 43(1), 137-149.

Kraay, J.H., 1980, 'Successive conceptions in the development of the Christian philosophy of Herman Dooyeweerd, Part 2: Description of the conceptions' [Opvolgende konsepsies in die ontwikkeling van die Christelike filosofie van Herman Dooyeweerd, Deel 2: Beskrywing van die konsepsies], Philosophia Reformata 44(2), 1-40.

Kuipers, T., 2011, Abraham Kuyper: An annotated bibliography, 1857-2010, Brill, Leiden. http://dx.doi.org/10.1163/ej.9789004211391.i-758

Kuyper, A., 1908, Nabij God te zijn: Meditatiën, Deel 1, Kok, Kampen.

Kuyper, A., 1912, Nabij God te zijn: Meditatiën, Deel 2, Kok, Kampen.

Kuyper, A., 1997, Near unto God: Daily meditations adopted for contemporary Christians by James Chaap, CRC Publications, Grand Rapids.

Malan, D.J., 1968, 'n Kritiese studie van die wysbegeerte van H.G. Stoker vanuit die standpunt van H. Dooyeweerd, Buijten \& Schipperheijn, Amsterdam.

Mitchell, C.V., 2007, Charts of philosophy and philosophers, Zondervan, Grand Rapids.

Polman, A.D.R., 1960, 'Monarchianisme' in F.W. Grosheide \& G.P. von Itterzon (reds.), Christelijke Encyclopedie, Vol. 5, p. 65, Kok, Kampen.

Popma, K.J., 1962, Levensbeschouwing, Deel 4, Buijten \& Schipperhijn, Amsterdam. 
Son, B.H., 1972, Science and person: A study of the idea of philosophy as a rigorous science in Kant and Husserl, Van Gorcum, Assen.

Spier, J.M., 1966, An introduction to Christian philosophy, transl. by D.H. Freeman, The Craig Press, Nutley, New Jersey.

Spier, J.M., 1972, Oriëntering in die Christelike wysbegeerte, vertl. deur H.J. Strauss \& D.F.M. Strauss, SACUM, Bloemfontein.

Steen, P.J., 1983, The structure of Dooyeweerd's thought, Wedge Publishing Foundation, Toronto.

Stellingwerff, J., 1987, Dr. Abraham Kuyper en de Vrije Universiteit, Kok, Kampen.

Stellingwerff, J., 1990, De Vrije Universiteit na Kuyper, Kok, Kampen.

Strauss, D.F.M., 2004, 'Intellectual influences upon the reformational philosophy of Dooyeweerd' [Intellektuele invloede op die reformatoriese filosofie van Dooyeweerd] Philosophia Reformata 69(2), 151-181.

Strauss, D.F.M., 2006a, 'Appropriating the legacy of Dooyeweerd and Vollenhoven' [Toeëiening van die nalatenskap van Dooyeweerd en Vollenhoven], Tydskrif vir Christelike Wetenskap 42(4),23-56.

Strauss, D.F.M., 2006b, 'The best known but least understood part of Dooyeweerd's philosophy [Die bekendste maar mins verstaande deel van Dooyeweerd se filosofie], Tydskrif vir Christelike Wetenskap 42(1), 61-80.

Strauss, D.F.M., 2009, Philosophy: Discipline of the disciplines, Paideia Press, Grand Rapids, Michigan.

Strauss, D.F.M. \& Botting, M., 2000, Contemporary reflections on the philosophy of Herman Dooyeweerd: A supplement to the collected works of Herman Dooyeweerd, The Edwin Mellen Press, Lewiston.

Taljaard, J.A.L., 1976, Polished lenses, Pro Rege Press, Potchefstroom.

Tol, A., 2010a, Philosophy in the making: D.H.Th. Vollenhoven and the emergence of reformed philosophy, Dordt College Press, Sioux Center, lowa.

Tol, A., 2010b, Promotie: Inleiding, e-pos, 19 November, tonyto158@gmail.com

Tol, A., 2011a, 'Vollenhoven and Dooyeweerd: Their emerging difference', Pape delivered at the International Symposium of the Association for Christian Philosophy, Amsterdam, 16-19 August 2011, (Unpublish).

Tol, A., 2011b, 'Reformational philosophy in the making' [Die ontstaan van reformatoriese filosofie], Philosophia Reformata 76(2), 187-215.

Tol, A., 2012, E-pos, 15 en 22 Mei, tonytol158@gmail.com

Van der Stelt, J.C., 1973, 'Kuyper's semi-mystical conception' [Kuyper se semisistieke konsepsie], Philosophia Reformata 38(2 \& 3),178-190.

Van der Stelt, J.C., 2012, Abraham Kuyper (1837-1920), Chapter 5 of a to be published book, Grand Rapids, Michigan.

Van der Walt, B.J., 2008, 'Antheunis Janse van Biggekerke 1890-1960: Morning star of a reformational worldview' in B.J. van der Walt, The eye is the lamp of the body, pp. 189-229, The Institute for Contemporary Christianity in Africa, Potchefstroom.

Van der Walt, B.J., 2010a, 'Wêreldwye belangstelling in die Kuyperiaanse reformatoriese lewensvisie - ook relevant vir Afrika', Tydskrif vir Christelike Wetenskap 46(1e \& $2 \mathrm{e}$ kwartaal), 43-60.

Van der Walt, B.J., 2010b, 'Wêreldwye belangstelling in Christelike wetenskapsbeoefenin en Christelike hoër onderwys', Tydskrif vir Christelike Wetenskap, 46 (2e kwartaal): $110-132$.
Van der Walt, B.J., 2011, 'Die Gereformeerd-skolastieke visie op die verhouding tussen God en mens by F. Gomarus (1563-1641) en J. Arminius (1560-1609): ' $n$ Historiesfilosofiese ondersoek', Tydskrif vir Geesteswetenskappe 51(3), 269-288.

Van der Walt, B.J. 2013a. 'Die Christelike filosofie van D.H.Th. Vollenhoven (1892-1978): Hoe dit ontstaan en ontwikkel het', In die Skriflig, 47(1).

Van der Walt, B.J. 2013b. 'H.G. Stoker (1899-1993) as Christelike filosoof: 'n Historiese legende en ikoon, of nog steeds 'n kontemporêre mentor?' In die Skriflig 47(1).

Van Schaik, J., 2005, In het hart is Hy te vinden: Een geschiedenis van de Christelijke mystiek, Uitgeverij Christofoor, Zeist.

Velema, W.H., 1957, De leer van die Heilige Geest bij Abraham Kuyper, Van Keulen, 's-Gravenhage.

Verburg, M.E., 1989, Herman Dooyeweerd: Leven en werk van een Nederlands christenwijsgeer, Ten Have, Baarn.

Vollenhoven, D.H.Th., 1918, De wijsbegeerte der wiskunde vanuit theïstisch standpunt, Wed. G. Van Soest, Amsterdam.

Vollenhoven, D.H.Th. (ed.), 1979, Ancient philosophical conceptions in problem-historical lay-out, 6th century $B C$ to 6 th $A D$, with an introduction by A. Tol, Filosofisch Instituut, V.U., Amsterdam.

Vollenhoven, D.H.Th., 1992, Vollenhoven als wijsgeer: Inleidingen en teksten, A. Tol \& K.A. Bril (reds.), Buijten \& Schipperheijn, Amsterdam.

Vollenhoven, D.H.Th., 2000, Schematische kaarten: Filosofishe concepties in probleem historisch verband, K.A. Bril \& P.J. Boonstra (reds.), De Zaak Haes, Amstelveen.

Vollenhoven, D.H.Th., 2005a, Wijsgerig Woordenboek, Bril, K.A. (red.), De Zaak Haes, Amstelveen.

Vollenhoven, D.H.Th., 2005b, The problem-historical method and the history of philosophy, K.A. Bril (ed.), De Zaak Haes, Amstelveen.

Vollenhoven, D.H.Th., 2011, Gastcolleges Wijsbegeerte: Erfenis voor het heden, K.A. Bril \& R.A. Nijhoff (reds.), De Zaak Haes, Amstelveen.

Wiskerke, J.R., 1962a, 'De anthropologie van Dr. A. Kuyper en de hartkwaal van de Wijsbegeerte der wetsidee' [Die antropologie van Dr. A. Kuyper en die hartkwaal van die Wysbegeerte van die wetsidee], Lucerna 4(4), 26-48.

Wiskerke, J.R., 1962b, 'Kuyper's anthropologie en de confessionele crisis van het synthetisch subjectivisme' [Kuyper se antropologie en die konfessionele krisis van synthetisch subjectivisme [Kuyper se antropologie
die sintetiese subjektivisme], Lucerna 4(4), 65-77.

Wolters, A.M., 1985, 'The intellectual milieu of Herman Dooyeweerd', in C.T. McIntire (ed.), The legacy of Herman Dooyeweerd: Reflections on critical philosophy in the Christian tradition, pp. 1-20, University Press of America, Lanham.

Young, W., 1952, Toward a reformed philosophy: The development of a protestant philosophy in Dutch Calvinist thought since the time of Abraham Kuyper, Piet Hein, Wever.

Young, W., 1966, 'Herman Dooyeweerd', in P. Hughes (ed.), Creative minds in contemporary theology, pp. 270-306, Eerdmans, Grand Rapids.

Zuidema, S.U., 1972, 'Common grace and Christian action in Abraham Kuyper', in H. van Dyke (transl.), Communication and confrontation, pp. 52-105, Wedge Publishers Foundation, Toronto.

Zylstra, B., 1975, 'Introduction', in L. Kalsbeek, Contours of a Christian philosophy, transl. by B. Zylstra \& J. Zylstra, pp. 14-33, Wedge Publishing Foundation, Toronto. 